\title{
Fluid evolution and ore deposition in the Harz Mountains revisited: isotope and crush-leach analyses of fluid inclusions
}

\author{
Stefan de Graaf ${ }^{1,2,3}$ (D) Volker Lüders ${ }^{4} \cdot$ David A. Banks $^{5} \cdot$ Marta Sośnicka $^{4} \cdot$ John J. G. Reijmer ${ }^{2} \cdot$ Heike Kaden $^{6}$ • \\ Hubert B. Vonhof ${ }^{1,3}$
}

Received: 9 August 2018 / Accepted: 25 March 2019/Published online: 25 April 2019

(C) The Author(s) 2019

\begin{abstract}
Hydrothermal fluid flow along fault zones in the Harz Mountains led to widespread formation of economic vein-type $\mathrm{Pb}-\mathrm{Zn}$ ore and $\mathrm{Ba}-\mathrm{F}$ deposits during the Mesozoic. We reconstruct the fluid flow system responsible for the formation of these deposits using isotope ratios $\left(\delta^{2} \mathrm{H}\right.$ and $\left.\delta^{18} \mathrm{O}\right)$ and anion and cation contents of fluid inclusions in ore and gangue minerals. Building forward on extensive studies in the 1980s and 1990s, our new geochemical data reveal that seawater evaporation brines, which most likely originated from Zechstein evaporites, descended deeply into Paleozoic rocks to leach metals at depth. In Jurassic times, these metal-rich brines episodically recharged along fault zones and mixed with shallow crustal $\mathrm{H}_{2} \mathrm{~S}$-bearing brines. Primarily in the Upper Harz Mountains, this mixing system led to the formation of economic $\mathrm{Pb}-\mathrm{Zn}-\mathrm{Cu}$ mineralization, which locally shows banded textures with alternations of sulfide minerals and quartz or carbonate (mostly calcite). In the Middle and Lower Harz Mountains, Zechstein-derived brines interacted with K- and F-bearing basement rocks and/or magmatic rocks to deposit fluorite mineralization upon ascent in the Upper Cretaceous. The proposed model of mineralizing fluids originating as (evaporated) seawater has been shown to hold for numerous basin-hosted base-metal sulfide and fluoride deposits elsewhere in Europe.
\end{abstract}

Keywords Hydrothermal veins $\cdot$ Fluid inclusion geochemistry $\cdot$ Fluid flow $\cdot$ Ore deposition $\cdot$ Harz Mountains

Editorial handling: H. A. Gilg

Electronic supplementary material The online version of this article (https://doi.org/10.1007/s00126-019-00880-w) contains supplementary material, which is available to authorized users.

Stefan de Graaf

stefan_de_graaf@hotmail.com

1 Department of Earth Sciences, VU University Amsterdam, De Boelelaan 1085, 1081HV Amsterdam, The Netherlands

2 College of Petroleum Engineering and Geosciences, King Fahd University of Petroleum and Minerals, Dhahran 31261, Saudi Arabia

3 Max Planck Institute for Chemistry, Hahn-Meitner-Weg 1, 55218 Mainz, Germany

4 GFZ German Research Centre for Geosciences, Telegrafenberg, 14473 Potsdam, Germany

5 School of Earth and Environment, University of Leeds, Leeds LS2 9JT, UK

6 Faculty of Computer Science, Mathematics and Natural Sciences, Leipzig University of Applied Sciences, Gustav-Freytag-Str. 42A, 04277 Leipzig, Germany

\section{Introduction}

Hydrothermal vein-type deposits in the Harz Mountains (Harz Mts.) were mined from the Middle Ages until the end of the twentieth century and have been the subject of scientific research for over 100 years (Fig. 1). Initial ideas on the origin of vein-type mineralization in the Harz Mts. strongly diverged. Whereas Stahl (1929) proposed a Mesozoic age for vein-type mineralization in the Upper Harz Mts., mid-twentieth century research generally assumed that the expulsion of magmatic fluids from Late Carboniferous granitic intrusions caused widespread deposition of sulfide, fluorite, and barite-rich veins (e.g., Dahlgrün 1950; Jacobsen and Schneider 1950; Wilke 1952).

From the 1980s onwards, a large number of geochemical studies (including isotope ratios, minor and trace element distributions, fluid inclusion microthermometry, isotope geochronology, etc.) revealed compelling evidence that the economically most important $\mathrm{Pb}-\mathrm{Zn}$, fluorite, and barite veintype mineralization in the Harz Mts. was deposited during the Mesozoic from highly saline $\mathrm{NaCl}-\mathrm{CaCl}_{2}$-rich brines (Möller et al. 1984; Behr et al. 1987; Behr and Gerler 1987; 


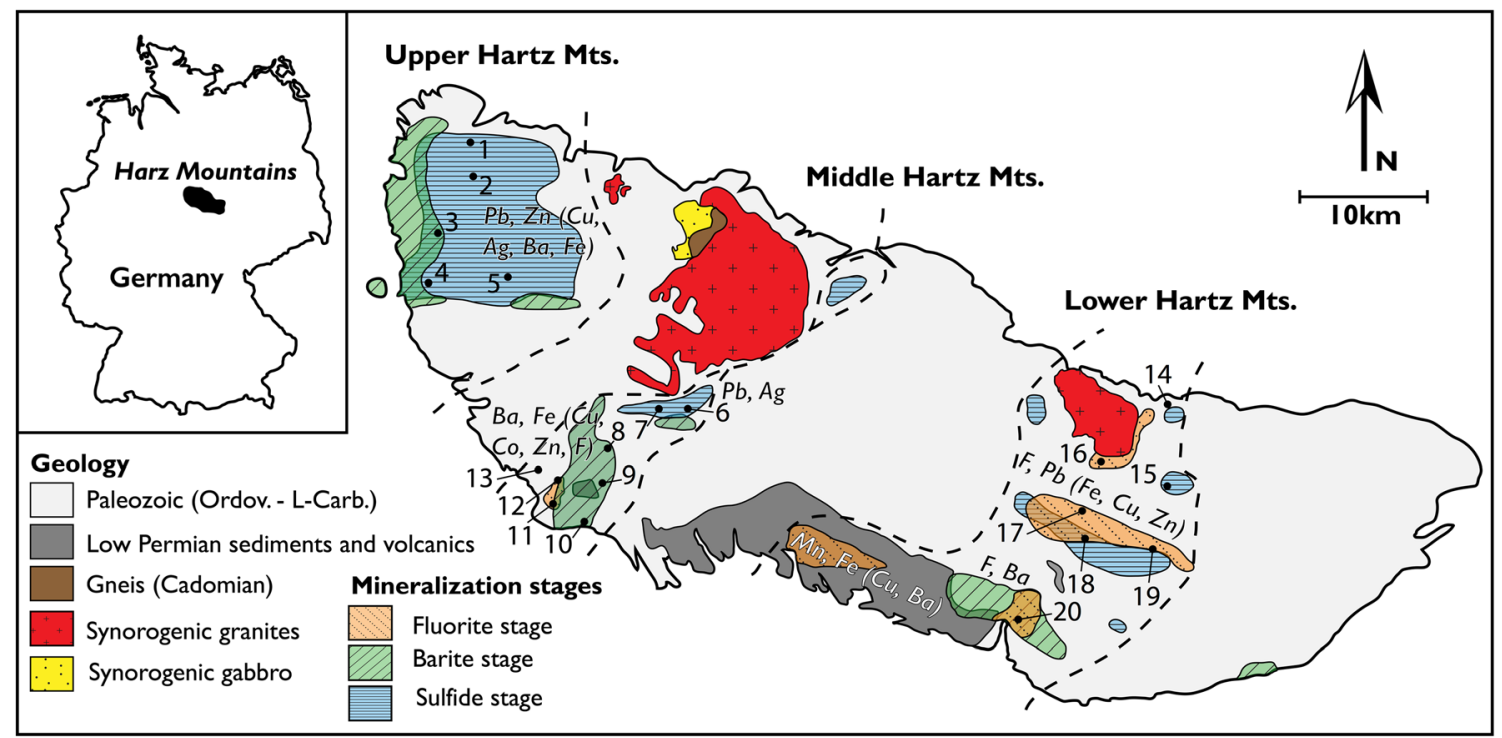

Fig. 1 Simplified geological map of the Harz Mts. modified after Lüders et al. (1993c), showing the distribution of the main Mesozoic ore deposits. The distribution of late Variscan mineralization in the Lower Harz Mts. is not shown. Sample locations: 1: Todberg vein, 2: Bockswiese; 3: Wildemann, 4: Bad Grund, 5: Clausthal, 6: Oder Valley, 7: St.
Andreasberg, 8: Wolkenhügel, 9: Hoher Trost, 10: Bad Lauterberg, 11: Andreasbachtal/Barbis, 12: Knollen, 13: Aurora Vein, 14: Gernrode, 15: Harzgerode, 16: Brachmannsberg/Siptenfelde, 17: Herzogschacht/ Biwende Vein, 18: Strassberg/Glasebach, 19: Strassberg-Neudorf vein, 20: Rottleberode
Lüders and Möller 1992; Haack and Lauterjung 1993; Hagedorn and Lippolt 1993; Lévêque and Haack 1993a, b; Lüders et al. 1993a, b; Zheng and Hoefs 1993; Schneider et al. 2003a). These new insights, thus, argued against a genetic link to Late Carboniferous granitic plutons. Möller and Lüders (1993) summarized the results of interdisciplinary research on the $\mathrm{Pb}-\mathrm{Zn}$, fluorite, and barite deposits in the Harz Mts. and concluded that mixing of metal-rich saline brines with reduced sulfur-bearing fluids gave rise to the deposition of quartz-sulfide and carbonatesulfide ores along WNW-ESE striking fracture zones. Subsequent mixing of metal-rich brines and sulfate-rich fluids led to the formation of economic barite mineralization in the Middle Harz Mts. Fluorite mineralization, which is completely absent in the Upper Harz Mts., marks the end of hydrothermal activity in the Middle and Lower Harz Mts. and is assumed to be related to the remobilization of fluorine from deep-seated reservoirs in Upper Cretaceous times.

Despite the achieved progress in characterizing the fluid flow system that underlies ore deposition in the Harz Mts., the precise origins of fluid salinity and mineral-forming constituents have remained a topic of debate. For example, whereas some studies suggest that ore-forming brines originated from Zechstein evaporites (Lüders and Möller 1992; Augustin 1993), other studies argue for major salinity uptake by basinal fluids through interaction with Paleozoic sediments or crystalline source rocks (Lévêque and Haack 1993a, b; Schneider et al. 2003b). Yet other studies suggest an important role of magmatic and metamorphic fluids (Möller et al. 1984; Behr et al. 1987). In this contribution, we use $\delta^{2} \mathrm{H}$ and $\delta^{18} \mathrm{O}$ data and anion and cation concentrations of fluid inclusion water trapped in hydrothermal vein minerals to trace the origin of the saline brines that were responsible for the deposition of Mesozoic $\mathrm{Pb}-\mathrm{Zn}$, barite, and fluorite mineralization and improve the existing fluid flow models.

For the acquisition of anion and cation concentrations, we performed crush-leach analysis on mineral bands from selected banded ores of the Upper Harz Mts. and present these data together with the so far unpublished crush-leach analysis data base of Kaden (2002). Microthermometric analysis was performed on fluid inclusions hosted in ore and gangue minerals from selected banded ores, and the data obtained are compared with previous data. For isotope analysis of fluid inclusion water, we applied a continuous-flow technique that consists of low-temperature crushing of samples and allows for on-line analysis of both $\delta^{2} \mathrm{H}$ and $\delta^{18} \mathrm{O}$ from a single water release (Vonhof et al. 2006). This technique bypasses typical analytical problems of thermal decrepitation techniques (e.g., Simon 2001). For example, the release of structural-bound water in $\mathrm{OH}$-groups by decrepitation at high temperatures is known to cause significant deviations in fluid inclusion isotope ratios for fluorite (Baatartsogt et al. 2007b) and quartz (Grant et al. 2003). The low-temperature crushing technique already has a record of producing reliable isotope data when applied to lowtemperature calcite veins (De Graaf et al. 2017, 2019; Bertotti et al. 2017). 


\section{Background}

\section{Geology of the Harz Mts.}

The Harz Mts. in Northern Germany are part of the metallogenetic belt of the Variscan Orogen in Central Europe. The Harz Mts. consist of strongly foliated and faulted Ordovician to Carboniferous low-grade to nonmetamorphic sedimentary successions of mainly siliciclastic composition (e.g., Franke 1989; Lüders et al. 1993c; Schneider et al. 2003a). The thickness of the Lower Devonian to Lower Carboniferous sequence (shales, limestones, sandstones, and greywackes) significantly increases toward the northwest reaching up to approximately $6 \mathrm{~km}$ in the Upper Harz Mts. (Bormann et al. 1989). Based on stratigraphic and structural features, the Harz Mts. are subdivided from west to east into three units, namely, the Upper, Middle, and Lower Harz Mts. (Fig. 1).

Autochthonous sedimentation accompanied by submarine extrusion of basic magma led to the formation of world-class SEDEX deposits in the Paleozoic sequence of the Upper and Middle Harz Mts. (Middle Devonian $\mathrm{Pb}-\mathrm{Zn}-\mathrm{Cu}$ deposit of Rammelsberg and $\mathrm{Fe}$ deposits in the Elbingeröder complex, respectively). Syn-orogenic magmatism is present as the Bad Harzburger gabbro intrusion in the northeast of the Upper Harz Mts. The emplacement of post-orogenic granitic melts in the Late Carboniferous and melaphyres and porphyries in Permian times was closely controlled by the tectonic framework inherited from the Variscan Orogeny (e.g., Lüders et al. 1993c; Mohr 1993). The Harz Mts. were eroded during the Rotliegend before thick layers of Zechstein evaporites precipitated in shallow marine conditions. Sedimentation of Mesozoic sandstones, limestones, evaporites, and clays continued until uplift of the Harz Mts. block that began in the Cretaceous. The uplift lasted throughout the Tertiary and caused erosion of the Mesozoic cover and exposure of the Paleozoic rock sequences at the surface.

\section{Vein mineralization in the Harz Mts.}

The Paleozoic rocks of the Harz Mts. host a wide variety of vein-type mineralization that mostly occurs along WNWESE striking shear zones up to $15 \mathrm{~km}$ long. The shear zones originate from normal or oblique strike-slip faulting along reactivated Variscan fault systems during the Mesozoic (Franzke and Zerjadtke 1993; Stedingk and Stoppel 1993). On a regional scale, the shear zones are mainly restricted to several NNE-SSW-oriented lineaments of elevated tectonic activity. The end of the Variscan Orogeny marked the onset of minor vein mineralization in the Harz Mts. The initial phases of late Variscan vein mineralization are only recognized in the Lower Harz Mts. and are characterized by minor fluorite, quartz-wolframite, and quartz-stibnite assemblages (Franzke and Zerjadtke 1993). Late Variscan vein mineralization was of only marginal economic interest, compared to the three main Mesozoic mineralization events referred to as the sulfide, barite, and fluorite mineralization stages (e.g., Lüders and Möller 1992; Lüders et al. 1993c).

$\mathrm{Pb}-\mathrm{Zn}( \pm \mathrm{Cu}-\mathrm{Ag})$ sulfide-stage deposits mainly occur in the Upper Harz Mts. and were of great economic importance with a total crude ore production of about 37 million tons over a mining period of about 500 years (Stedingk 2012). The sulfide mineralization stage, which developed in up to 20-mthick fault zones after an early pre-ore stage I (with minor quartz-hematite-carbonate-pyrite-chalcopyrite, bleaching and reddening of wall rocks), is subdivided into several substages (IIa-d and IIIa-b) that are dominated by different ore and gangue minerals and ore patterns (Stedingk and Stoppel 1993). Quartz-calcite-galena and later sphalerite-calcite banded ores are characteristic of the mineralization stage II. At the Bad Grund deposit, about $50 \%$ of the total mineralization precipitated during substages IIIa and $\mathrm{b}$ and mostly consists of galena, pyrite, quartz, and carbonates (Stedingk and Stoppel 1993). The sulfide mineralization stage dates back to the Lower Jurassic and is primarily recognized in the Upper Harz Mts. (Haack and Lauterjung 1993). At that time, the Harz Mts. were covered by up to approximately $2000 \mathrm{~m}$ of Zechstein evaporites and Mesozoic sediments (Franzke and Zerjadtke 1993). Sulfide-stage vein deposits mostly precipitated at temperatures between 120 and $170{ }^{\circ} \mathrm{C}$ as measured from fluid inclusion studies (Lüders et al. 1993a; this study) and often display a banded texture with quartz-sulfide or carbonate-sulfide alternations (Fig. 2). It is noteworthy that the metal content of the veins decreases with depth, whereas the calcite content increases (Stedingk 1993). For example,

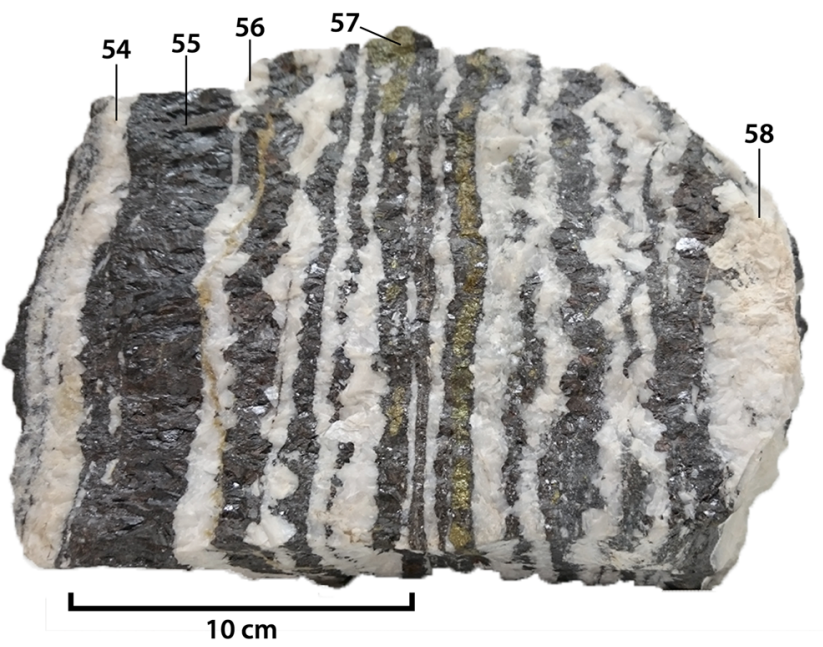

Fig. 2 Banded texture of a calcite-sulfide-stage vein sample retrieved from the Bad Grund deposit (Westfield Orebody II, 19th level). Banding results from cyclic variations in the composition of the mineralizing fluid. White, black, and goldish bands represent calcite, sphalerite, and chalcopyrite, respectively. Numbers correspond to ' $\mathrm{HZ}$ ' samples listed in ESM Tables 1-3 
the Lautenthal ore body is composed of thick, almost barren calcite at a depth of $400 \mathrm{~m}$ below sea level (Stedingk 1993).

After the sulfide mineralization stage, continued uplift of the Harz Mts. in the Cretaceous allowed for an influx of meteoric surface water and the deposition of barite mineralization at shallow crustal levels (Stoppel et al. 1983). Fluid salinity, as well as precipitation temperatures of the shallow crustal barite deposits $\left(<100{ }^{\circ} \mathrm{C}\right)$, shows a sharp decrease with respect to the preceding sulfide mineralization stage (Lüders et al. 1993a). Due to an increased uplift of the northern part of the Harz Mts., barite stage mineralization is only preserved along the southern and western margins of the Harz Mts. (Lüders and Möller 1992).

Fluorite veins accompanied by subordinate amounts of quartz and calcite characterize the third and final main Mesozoic mineralization event (Fig. 3). The occurrence of fluorite veins is restricted to the Middle and Lower Harz Mts. Fluorite mineralization in the Middle Harz Mts. along structures south of the Brocken granite was only of minor economic importance. Considerable fluorite mineralization in the vicinity and south of the Ramberg granite in the Lower Harz Mts. was mined until 1990. After the main Mesozoic mineralization events, only remobilization of primarily carbonates occurred (Stoppel et al. 1983).

\section{Methods}

\section{Fluid inclusion microthermometry}

Microthermometric measurements of fluid inclusions hosted in sphalerite and quartz from banded ores were conducted using a Fluid Inc. USGS heating freezing system mounted on a BX 50 Olympus microscope. Fluid inclusions in calcite were studied using a Linkam THSM 600 system on a BX53M Olympus microscope. Both heating/freezing stages were calibrated with synthetic fluid inclusion standards supplied by Synflinc.

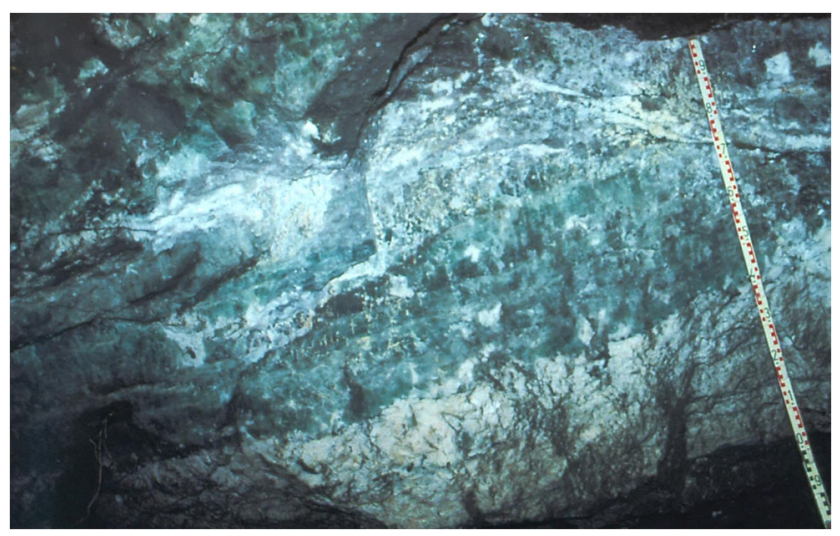

Fig. 3 Fluorite-calcite mineralization at the ninth level of the StrassbergBiwender vein, Lower Harz Mts. Calcite and fluorite are strongly intermixed, pointing to a close co-genetic relationship

\section{Bulk crush-leach analysis}

Bulk crush-leach analysis of fluid inclusions was carried out at the University of Leeds following the methodology described in detail by Banks et al. (2000). In total, 63 samples of quartz, calcite, galena, sphalerite, fluorite, and siderite from banded ores and sulfide- or fluorite-stage mineralization (ESM Table 1) were crushed to a 1-2-mm grain size. Quartz and fluorite samples were cleaned by boiling in aqua regia, followed by boiling several times in 18.2 $\mathrm{M} \Omega$ water. Samples of other mineral types were only boiled several times in 18.2 $\mathrm{M} \Omega$ water. Subsequently, the cleaned samples were dried. Approximately 0.5 to $1 \mathrm{~g}$ of purified sample material was manually crushed with an agate mortar and pestle. The resulting mineral powder was leached with $18.2 \mathrm{M} \Omega$ water and filtered through a $0.2-\mu \mathrm{m}$ nylon mesh prior to analysis. Ion chromatography was used for analysis of the anions $\mathrm{Cl}$, $\mathrm{Br}$, and $\mathrm{SO}_{4}$ in the leachate solutions. The cations $\mathrm{Na}, \mathrm{K}$, and Li were measured using flame emission spectroscopy. The detection limits for the elements analyzed are as follows: $\mathrm{Na}=20 \mathrm{ppb}, \mathrm{K}=25 \mathrm{ppb}, \mathrm{Li}=1 \mathrm{ppb}, \mathrm{Cl}=20 \mathrm{ppb}, \mathrm{Br}=$ $1 \mathrm{ppb}$, and $\mathrm{SO}_{4}=30 \mathrm{ppb}$ with an average precision, as determined from series of replicate analyses, of better than $10 \%$ relative standard deviation.

Concentrations of $\mathrm{SO}_{4}$ from some fluid inclusions hosted by quartz, calcite, and fluorite are unrealistically high due to the presence of calcium sulfates in calcite and small micron-sized sulfide inclusions in the other minerals. Therefore, we cannot rely on the validity of $\mathrm{SO}_{4}$ analyses in general. Calcium was not measured in calcite and fluorite. In sphalerite, galena, and some quartz samples, the concentrations of $\mathrm{Ca}$ were unrealistically high due to the presence of micron-sized Ca-bearing solid inclusions in the host minerals. Instead, absolute calcium concentrations were calculated from the charge balance, which indicates a lack of cations. Calcium is assumed to account for the lack of cations, as fluid inclusion microthermometry strongly suggests that the brines in the Harz Mts. are dominated by $\mathrm{NaCl}-\mathrm{CaCl}_{2}-\mathrm{H}_{2} \mathrm{O}$ (Lüders et al. 1993a).

\section{Isotope analysis}

In total, 50 vein samples were selected from multiple outcrops and mines throughout the Harz Mts. for isotope analysis (ESM Table 1; code HZ). The suite of samples comprises both banded ores from the Upper Harz Mts. and regular vein-type deposits. The minerals analyzed cover the three main Mesozoic mineralization stages and include calcite, quartz, fluorite, barite, and the metal sulfides sphalerite, galena, and chalcopyrite. Part of the samples used for isotope analyses is the same as used for crush-leach analysis (ESM Table 1).

Fluid inclusion isotope analysis, with the methodology developed by Vonhof et al. (2006), was used to obtain $\delta^{18} \mathrm{O}_{\mathrm{w}}$ and $\delta^{2} \mathrm{H}_{\mathrm{w}}$ values of bulk fluid inclusion waters. This technique 
allows for fluid inclusion isotope characterization of mineral samples of up to $2 \mathrm{~g}$. The first step in the analytical procedure consists of crushing the sample at $110{ }^{\circ} \mathrm{C}$ in the Amsterdam device, which is a crusher unit connected to a continuous-flow pyrolysis furnace (ThermoFinnigan TC-EA). The submicroliter amount of water that is liberated due to the opening of inclusions is vaporized and transported to a TC-EA reactor tube, which separates the water vapor into $\mathrm{H}_{2}$ and $\mathrm{CO}$ gas as a result of reaction with glassy carbon at $1400{ }^{\circ} \mathrm{C}$. A cryo-focusing technique is applied prior to entry into the reactor tube to generate a water pulse short enough to be analyzed. The $\mathrm{H}_{2}$ gas and $\mathrm{CO}$ gas are consecutively measured in a continuous-flow isotope-ratio mass spectrometer (ThermoFinnigan Delta XP). A rapid magnet peak jump between the entries of $\mathrm{H}_{2}$ gas and $\mathrm{CO}$ gas allows for analysis of both hydrogen and oxygen isotopes from a single water release. Isotope values of fluid inclusion water are reported as $\delta^{2} \mathrm{H}_{\mathrm{w}}$ and $\delta^{18} \mathrm{O}_{\mathrm{w}}$ ratios relative to VSMOW. Routinely measured water standards, following the analytical protocol, are typically reproducible $(1 \sigma)$ within $0.3 \%$ o for $\delta^{18} \mathrm{O}_{\mathrm{w}}$ and $2.0 \%$ for $\delta^{2} \mathrm{H}_{\mathrm{w}}$.

Crushed calcite samples were retrieved after fluid inclusion isotope analysis and then analyzed for carbon and oxygen isotopes on a Thermo Finnigan Delta+ mass spectrometer equipped with a GASBENCH II preparation device. Around $10 \mu \mathrm{g}$ of sample material was placed in a He-filled 12-ml exetainer vial before sample digestion in concentrated anhydrous $\mathrm{H}_{3} \mathrm{PO}_{4}$ at a temperature of $45^{\circ} \mathrm{C}$. The generated $\mathrm{CO}_{2}-$ $\mathrm{He}$ gas mixture was transported to the GASBENCH II in a He carrier flow. In the GASBENCH II, water was extracted from the gas through nafion tubing, and $\mathrm{CO}_{2}$ was analyzed in the mass spectrometer after extraction of residual gases in a $\mathrm{GC}$ column. Each sample was measured at least twice to determine the analytical precision. Isotope values for calcite are reported as $\delta^{13} \mathrm{C}_{\mathrm{c}}$ and $\delta^{18} \mathrm{O}_{\mathrm{c}}$ ratios relative to VPDB. The typical reproducibility $(1 \sigma)$ of routinely analyzed calcite standards is better than $0.10 \%$ for both $\delta^{13} \mathrm{C}_{\mathrm{c}}$ and $\delta^{18} \mathrm{O}_{\mathrm{c}}$.

\section{Results}

\section{Fluid inclusion characteristics}

The petrography of fluid inclusions and their characteristics as determined from microthermometry in the different minerals from vein deposits in the Harz Mts. have been wellcharacterized (e.g., Adeyemi 1982; Behr et al. 1987; Behr and Gerler 1987; Lüders 1988; Lüders and Möller 1992; Augustin 1993; Lüders et al. 1993a; Lüders and Reutel 1998). Ore and gangue minerals from the Mesozoic veintype deposits host abundant high-salinity aqueous two-phase fluid inclusions (Fig. 4). Three-phase (liquid + vapor + halite) inclusions are rare and, when present, are commonly hosted in fluorite from veins in the Lower Harz Mountains (Fig. 4f).
They typically show irregular shapes and occur along secondary trails. Only barite mineralization is characterized by the presence of mostly all-liquid aqueous inclusions. The majority of homogenization temperatures fall between 100 and $160{ }^{\circ} \mathrm{C}$ (Lüders et al. 1993a); only a few primary fluid inclusions with homogenization temperatures above $200{ }^{\circ} \mathrm{C}$ have been reported (Lüders et al. 1993a; Augustin 1993). However, considering the Harz Mts. were covered by about $2 \mathrm{~km}$ of Zechstein evaporites and Mesozoic sediments, nearly lithostatic pressure conditions at the time of ore formation have to be taken into account (Franzke and Zerjadtke 1993). Under such pressure conditions of about 500 bars, a correction of about $20^{\circ} \mathrm{C}$, added to the measured homogenization temperatures, is needed to obtain the true trapping temperatures (Potter 1977).

In some instances, low-temperature microthermometry of high-salinity fluid inclusions in quartz from the sulfide stage and fluorite from the fluorite stage revealed phase transitions (i.e., eutectic temperatures and coupled melting of ice and hydrohalite) that are comparable to experimental data of Davis et al. (1990) and Spencer et al. (1990), indicating a brine composition of about $28-30 \mathrm{NaCl}-\mathrm{CaCl}_{2}$ equiv. wt\% and a variable cation content of 3-15 $\mathrm{NaCl}$ equiv. wt\% and 15-27 $\mathrm{CaCl}_{2}$ equiv. wt\% (Lüders et al. 1993a). However, most of the reported first melting temperatures of fluid inclusions are below the eutectic of the $\mathrm{CaCl}_{2}-\mathrm{NaCl}-\mathrm{H}_{2} \mathrm{O}$ system. Although this could have indicated the presence of significant concentrations of Li (Borisenko 1998; Zhang and Weisbrod 1988), we know from crush-leach analyses that $\mathrm{Li}$ is not present in the fluids in the concentrations required to lower the eutectic to the observed values. Hence, the low first melting temperatures are most likely due to observing a metastable eutectic in the $\mathrm{CaCl}_{2}-\mathrm{NaCl}-\mathrm{H}_{2} \mathrm{O}$ system (Davis et al. 1990).

Chevron quartz, which commonly occurs in hydrothermal $\mathrm{Pb}-\mathrm{Zn}$ vein mineralization of the Harz Mts., hosts primary and pseudosecondary fluid inclusions in and between growth zones (Fig. 4e). Fluid inclusions hosted in chevron quartz from $\mathrm{Pb}-\mathrm{Zn}$ veins in the Harz Mts. generally show narrow ranges of ice melting temperatures for individual mineralization substages (Adeyemi 1982; Lüders et al. 1993a; Fig. 5). In veins from the eastern vicinity of the Brocken granite, on the other hand, ice melting and homogenization temperatures may vary considerably between distinct growth zones of single chevron quartz crystals. This is suggestive of, locally, the presence of a lower salinity fluid together with the highsalinity $\mathrm{CaCl}_{2}-\mathrm{NaCl}-\mathrm{H}_{2} \mathrm{O}$ brines (Behr et al. 1987; Lüders 1988; Lüders et al. 1993a). Although trails with secondary fluid inclusions are also present in chevron quartz, their contribution to the total fluid inclusion water budget is negligible as their contents are volumetrically insignificant.

Fluorite-hosted fluid inclusions that bear halite daughter crystals show relatively low homogenization temperatures in the range of 100 to $120^{\circ} \mathrm{C}$, followed by melting of halite at temperatures between 150 and $180^{\circ} \mathrm{C}$ (Augustin 1993). 


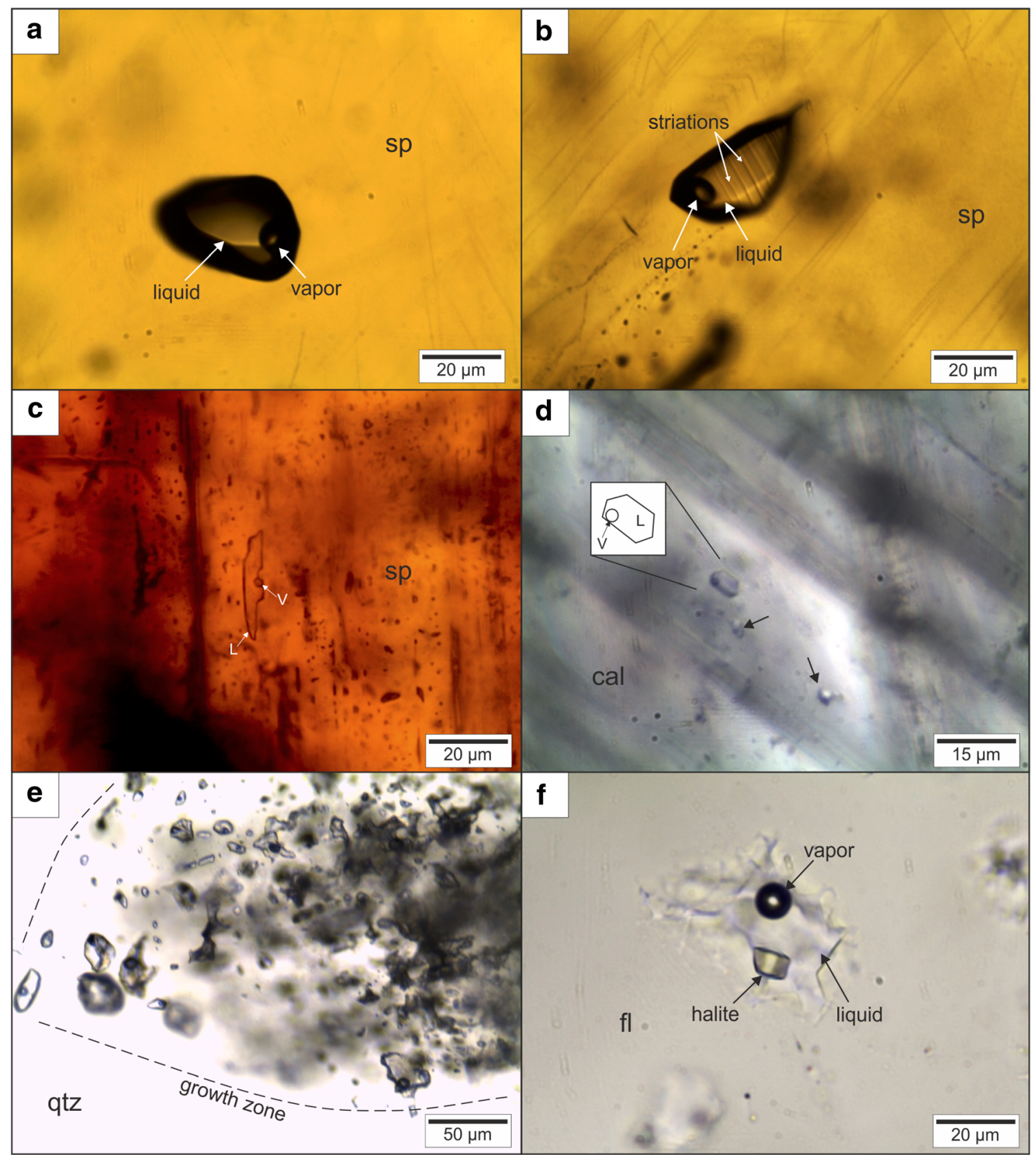

Fig. 4 Photomicrographs of fluid inclusions. a Primary two-phase ( $\mathrm{L}+$ V) aqueous fluid inclusion hosted in yellow sphalerite, Clausthal, Upper Harz Mts. b Primary two-phase $(\mathrm{L}+\mathrm{V})$ aqueous inclusion with visible striations hosted in yellow sphalerite, Clausthal. c Primary two-phase ( $\mathrm{L}+$ $\mathrm{V}$ ) aqueous inclusion decorating a growth zone in orange sphalerite from banded Zn ore, Bad Grund, Upper Harz Mts. d Small primary two-phase

\section{Fluid inclusions in sulfide-stage minerals}

Fluid inclusions in ore and gangue minerals from the sulfide stage of the Upper Harz Mts. have previously received little attention due to their less frequent abundance and small size. Most data were obtained from studies of fluid inclusions in quartz and calcite, and a compilation of the data is given by Lüders et al. (1993a). In this study, microthermometric
$(\mathrm{L}+\mathrm{V})$ aqueous fluid inclusions located between calcite twin lamellae, banded Zn ore, Bad Grund, Harz Mts. e Quartz-hosted primary two-phase $(\mathrm{L}+\mathrm{V})$ aqueous inclusions within the growth zone, Glasebach, Strassberg-Neudorf vein, Lower Harz Mts. f Fluorite-hosted primary three-phase $(\mathrm{L}+\mathrm{V}+\mathrm{H})$ aqueous inclusion, Brachmannsberg, Lower Harz Mts.

measurements were conducted on sphalerite, calcite, and quartz from the sulfide substages IIb- $d$ and IIIa of the main sulfide stage. The samples studied are from banded ore specimens from the Bad Grund deposit and the Burgstätte vein at Clausthal, in the Upper Harz Mts. (Fig. 1). Primary fluid inclusions in sphalerite from banded ores predominantly occur as isolated inclusions or are arranged along distinct growth bands (Fig. 4a-c). Primary aqueous two-phase inclusions in calcite from banded 


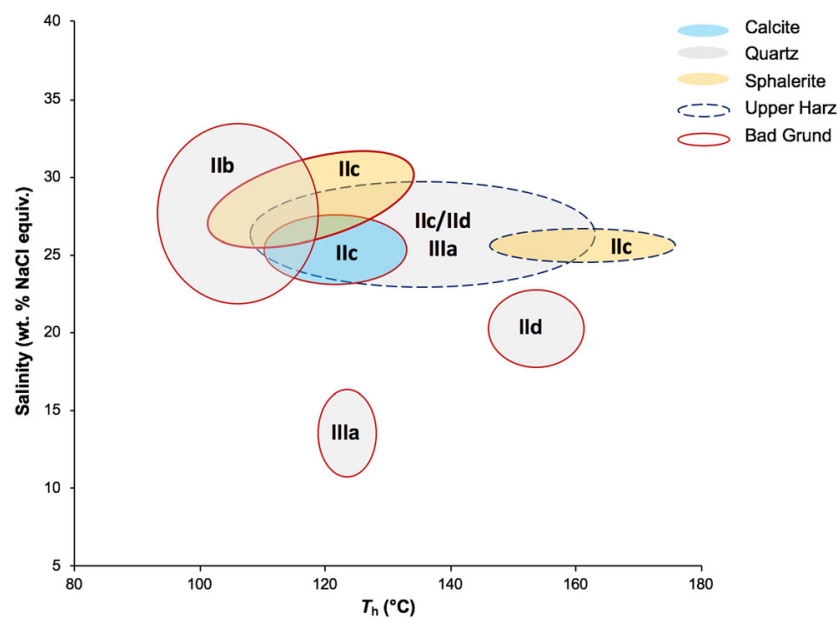

Fig. 5 Salinity vs Th diagram of fluid inclusions hosted in gangue minerals and sphalerite from different substages of the main sulfide stage of the Upper Harz Mts. A distinction is made between samples from the Bad Grund deposit and other veins in the Upper Harz Mts., which come from Clausthal, Todberg, Schulenberg, Bockswiese, and Lautenthal. Ranges for salinity of substages IId and IIIa (Bad Grund) are taken from Adeyemi (1982)

ores are typically small and their sizes are less than $10 \mu \mathrm{m}$ (Fig. 4d). Calcite from banded ores is characterized by narrow twin lamellae that are not cross-cut by trails of secondary fluid inclusions. Quartz samples from banded ores and other Mesozoic vein mineralization of the Harz Mts. are characterized by distinct zoning. Primary fluid inclusions associated with growth zones are abundant (Fig. 4e).

The studied fluid inclusions in all minerals contain a highsalinity fluid which decreases in salinity at the Bad Grund deposit in substage IId and the subsequent stage IIIa (Fig. 5). Homogenization temperatures increase from substage IIb through to IId, but then decrease in quartz from substage IIIa (Fig. 5). Banded ore sphalerite-hosted fluid inclusions have a similar range of homogenization temperatures and slightly higher salinities than the fluid inclusions in calcite from adjacent bands.

Banded ores from the Burgstätte vein at Clausthal, which is located some $6 \mathrm{~km}$ east of the Bad Grund, were deposited from fluids of similar salinity, but at higher temperatures than the banded ores from the Bad Grund deposit. Fluid inclusions in quartz from the Burgstätte vein at Clausthal have the same salinity and Th range as fluid inclusions in several other veins from the Upper Harz Mts. (including Todberg, Schulenberg, Zellerfeld, and Lautenthal; ESM Table 2), which are included in field IIc/IId/IIIa in Fig. 5 for comparison. The highest homogenization temperatures were measured in primary fluid inclusions hosted in sphalerite from the Burgstätte vein at Clausthal (ESM Table 2).

\section{Crush-leach analyses}

In order to elucidate the source(s) of salinity, anion and cation concentrations of fluid inclusions hosted in ore and gangue minerals from various parts of the Harz Mts. and in different mineralization stages were analyzed (ESM Table 3A-3B). The data are plotted in a $\mathrm{Na}-\mathrm{Cl}-\mathrm{Br}$ diagram, as proposed by Walter et al. (1990). This diagram can be used to discriminate between different solute sources and, furthermore, has the advantage that molar ratios are unaffected by dilution with meteoric water (Kesler et al. 1995).

In $\mathrm{Na} / \mathrm{Br}$ vs $\mathrm{Cl} / \mathrm{Br}$ diagrams of the different mineralization stages, the data plot close to the seawater evaporation trend (Fig. 6), which indicates that the ore-forming fluids were mainly marine in origin. The position of the data slightly to the left of the seawater evaporation line is indicative of loss of $\mathrm{Na}$ through water-rock exchange
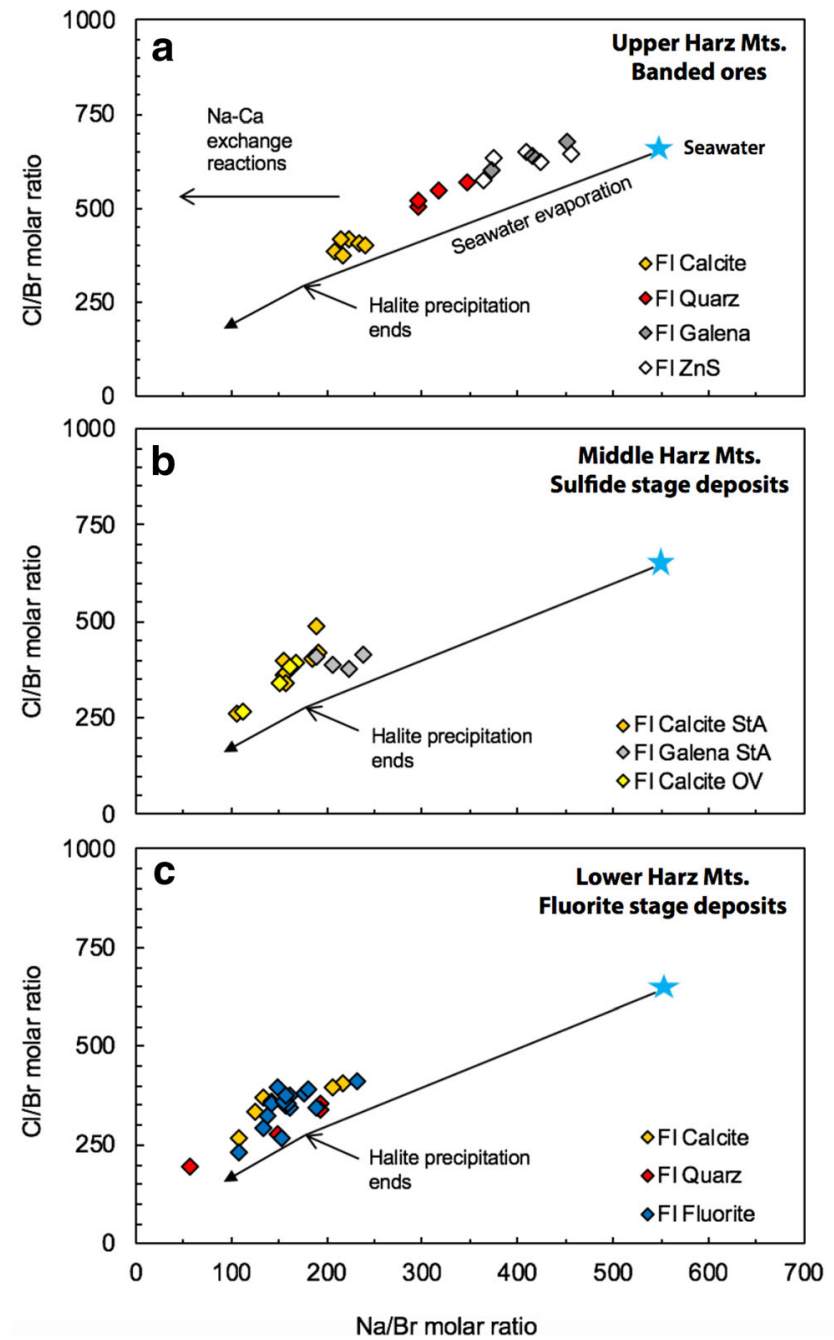

Fig. 6 a-c $\mathrm{Na} / \mathrm{Br}$ vs $\mathrm{Cl} / \mathrm{Br}$ diagrams demonstrate that the fluid system in the Harz Mts. is dominated by evaporative marine fluids. Data of banded ores from the Upper Harz Mts. (a) show that multiple fluid sources were present in the system; fluid inclusions in quartz and calcite display more evaporative signatures than associated sulfides. Minor deviations from the evaporative trend may be related to WRI. Abbreviations: StA-St. Andreasberg; OV-Oder Valley 
reactions. For example, $\mathrm{Na}$ may be lost from fluids through exchange with $\mathrm{Ca}$ in plagioclase (Davisson and Criss 1996) or through albitization of K-feldspar (Banks et al. 2002; Möller et al. 2017). Banded ore sulfides from the Upper Harz Mts., galena from the St. Andreasberg $\mathrm{Pb}-\mathrm{Ag}$ deposit in the Middle Harz Mts., and fluorite mineralization show $\mathrm{K}$ enrichment in $\mathrm{Na} / \mathrm{K}$ vs $\mathrm{Cl} / \mathrm{Br}$ diagrams (Fig. $7 \mathrm{a}-\mathrm{c}$ ), which indicate that $\mathrm{Na}-\mathrm{K}$ exchange between fluids and minerals was an important process.

Fluid inclusions in banded ores from the Upper Harz Mts. have $\mathrm{Cl} / \mathrm{Br}$ molar ratios that cover a large range along the seawater evaporation line (Fig. 6a). Fluid inclusions in galena and sphalerite from banded ores have $\mathrm{Cl} / \mathrm{Br}$ molar ratios similar or slightly lower to seawater, whereas quartz and
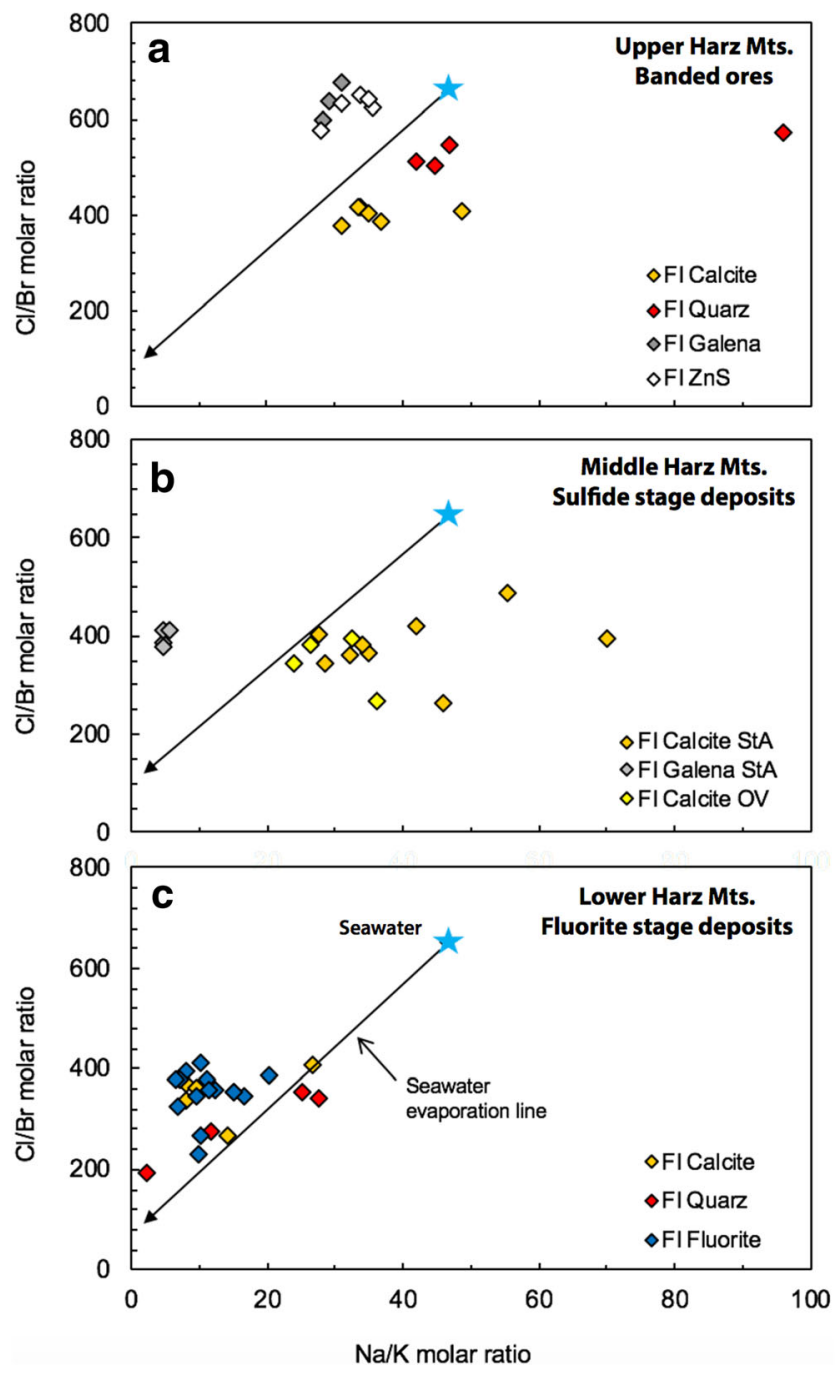

Fig. 7 a-c $\mathrm{Na} / \mathrm{K}$ vs $\mathrm{Cl} / \mathrm{Br}$ diagrams demonstrate a clear influence of $\mathrm{Na}-$ $\mathrm{K}$ alteration processes (e.g., WRI with $\mathrm{K}$-bearing minerals). $\mathrm{Na} / \mathrm{K}$ molar ratios of minerals in the Upper Harz (a) point to the presence of multiple fluids in the system. Fluorite, calcite, and quartz from the Lower Harz (c) have overlapping $\mathrm{Na} / \mathrm{K}$ molar ratios, indicating a close co-genetic relationship. Abbreviations: StA—St. Andreasberg; OV—Oder Valley calcite samples from adjacent bands have considerably lower fluid inclusion $\mathrm{Cl} / \mathrm{Br}$ molar ratios. It is conspicuous that fluid inclusions hosted in quartz from quartz-sulfide banded ores yield more variable but always higher $\mathrm{Cl} / \mathrm{Br}$ and $\mathrm{Na} /$ $\mathrm{Br}$ molar ratios than fluid inclusions in calcite from carbonate-sulfide ores. Also in $\mathrm{Na} / \mathrm{K}$ vs $\mathrm{Cl} / \mathrm{Br}$ diagrams (Fig. 7a), sulfides and gangue minerals from the banded ores plot in distinctive areas, possibly due to the interaction of fluids with different lithologies either in the fluid reservoir or along the flow path to the sites of ore deposition. There are no clear patterns in $\mathrm{Cl} / \mathrm{Br}, \mathrm{Na} / \mathrm{Br}$, and $\mathrm{Na} / \mathrm{K}$ molar ratios of fluid inclusions in sulfide- and fluorite-stage mineralization in the Middle and Lower Harz Mts. (Figs. 6b, c and $7 \mathrm{~b}, \mathrm{c})$. In a Na-Cl-Br diagram, the crush-leach data of fluorite-stage mineralization from the Lower Harz Mts. plot further away from the seawater end-member along the seawater evaporation trend compared to banded ores (Fig. 6c).

$\mathrm{Li}$ was analyzed in the fluids to confirm if the low eutectic temperatures were due to the presence of high Li concentrations. The analyses, however, show that $\mathrm{Li}$ concentrations were too low for this to account for the first melting temperatures.

\section{Fluid inclusion isotope data}

Water yields $(0.1$ to $0.8 \mu \mathrm{l})$ were sufficient to obtain reliable data for 46 samples (ESM Table 4). A complete overview of fluid inclusion isotope data is presented in Fig. 8. Fluorite has the highest isotope values ranging from 2.5 to $6.5 \%$ ofor $\delta^{18} \mathrm{O}_{\mathrm{w}}$ and -31 to $5 \%$ o for $\delta^{2} \mathrm{H}_{\mathrm{w}}$ with a positive correlation between the two variables. A similar positive correlation is present in vein-type calcite and quartz deposits in the Middle and Lower Harz, albeit shifted toward lower isotope values ( -7.8 to $-0.4 \%$ o for $\delta^{18} \mathrm{O}_{\mathrm{w}}$ and -54 to $-15 \%$ ofor $\delta^{2} \mathrm{H}_{\mathrm{w}}$ ). Barite stands out with respect to the other analyzed minerals for its relatively depleted values, which are as low as $-8.8 \%$ for $\delta^{18} \mathrm{O}_{\mathrm{w}}$ and $-72 \%$ for $\delta^{2} \mathrm{H}_{\mathrm{w}}$.

Fluid inclusion isotope signatures of metal sulfides from the Bad Grund $\mathrm{Pb}-\mathrm{Zn}$ banded ores in the Upper Harz range from 0.4 to $2.9 \%$ o for $\delta^{18} \mathrm{O}_{\mathrm{w}}$ and from -24 to $-7 \%$ o for $\delta^{2} \mathrm{H}_{\mathrm{w}}$ (Fig. 8). These values are quite similar to fluorite from occurrences in the Middle Harz Mts. and fluorite deposits in the Lower Harz Mts. Fluid inclusion water in calcite and quartz from the banded ores plot in isotopically distinct fields and toward lower $\delta^{18} \mathrm{O}_{\mathrm{w}}$ and $\delta^{2} \mathrm{H}_{\mathrm{w}}$ values compared to the sulfide minerals.

\section{Carbon and oxygen isotope ratios of calcite}

Carbon and oxygen isotope ratios of calcite from banded ores and other vein-type occurrences throughout the Harz Mts. are positively correlated and range from -17.1 to $-10.8 \%$ for $\delta^{18} \mathrm{O}_{\mathrm{c}}$ and -10.6 to $-6.8 \%$ for $\delta^{13} \mathrm{C}_{\mathrm{c}}$ (Fig. 9; ESM 
Fig. 8 Fluid inclusion isotope data of early-stage banded ores from the Upper Harz (above) and Mesozoic vein-type deposits across the Harz Mts. (below). Whereas fluid inclusion isotope signatures of fluorite and metal sulfides probably directly represent paleo-mineralizing fluids, those of the oxygen-bearing phases may have experienced a post-depositional depletion in ${ }^{18} \mathrm{O}$ due to temperature-forced isotope re-equilibration. Considerable variations in $\delta^{2} \mathrm{H}_{\mathrm{w}}$ exist among the various mineral types and evidence the existence of distinct fluid reservoirs and fluid mixing. The global meteoric water line (GMWL), which expresses the relation between $\delta^{2} \mathrm{H}_{\mathrm{w}}$ and $\delta^{18} \mathrm{O}_{\mathrm{w}}$ in natural terrestrial waters as a global average (Craig 1961), is shown for reference
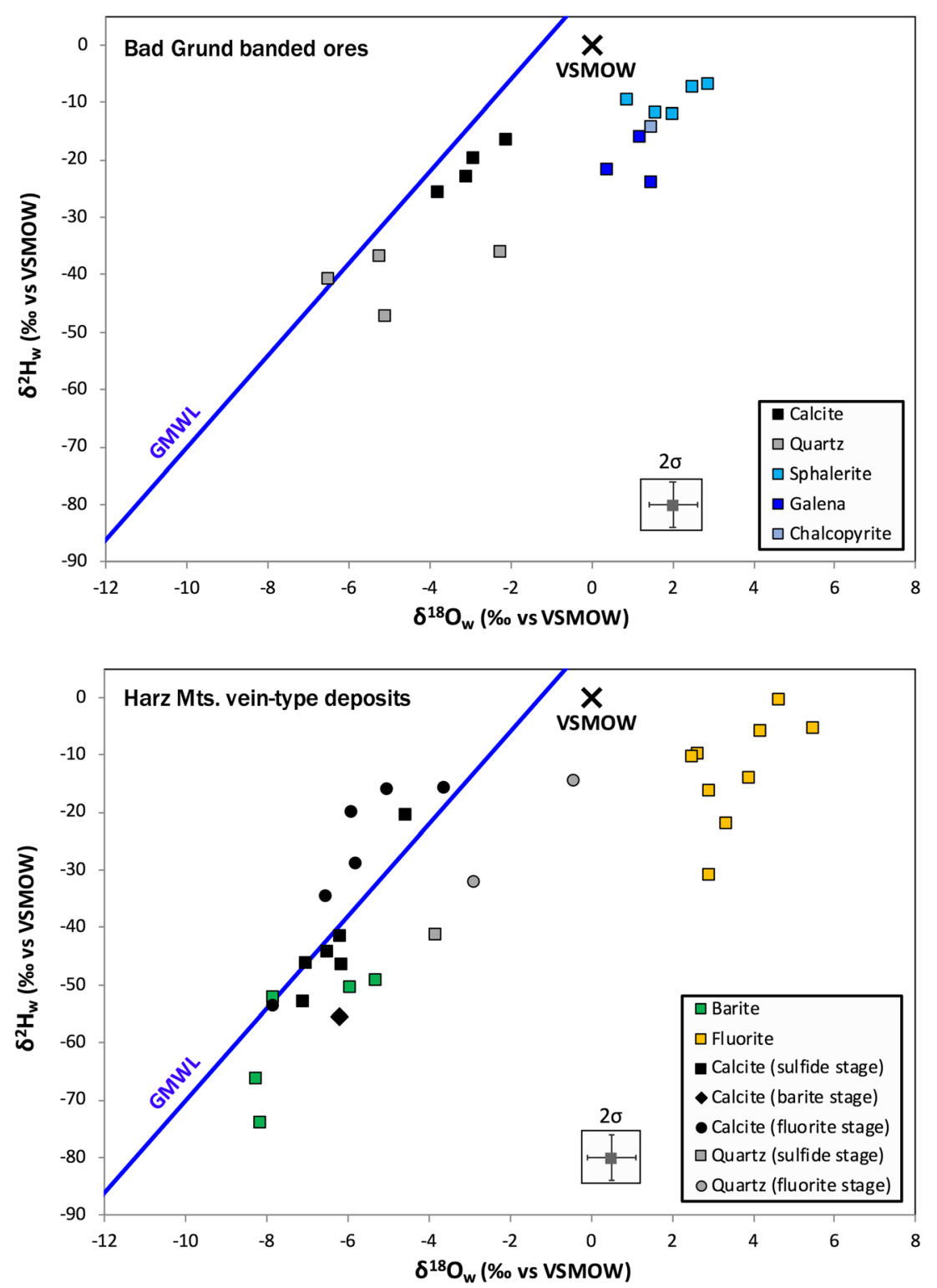

Table 4). These data are similar to extensive isotope analyses of calcite from the Harz Mts. by Zheng and Hoefs (1993), who suggested that water-rock interactions or temperature-dependent fractionation effects may underlie the clear co-variation between carbon and oxygen isotopes. The systematic isotope depletion of fluorite-stage calcite with respect to the older sulfide-stage calcite could be related to a change in water-rock interaction intensities, fluid temperatures, and/or sources for dissolved inorganic carbon (DIC). The carbon and oxygen isotope data of calcite samples do not provide signs of recrystallization, since recrystallized calcite from the Harz Mts. typically plots in a distinct field toward higher $\delta^{18} \mathrm{O}_{\mathrm{c}}$ values and lower $\delta^{13} \mathrm{C}_{\mathrm{c}}$ values (Lüders and Möller 1992; Zheng and Hoefs 1993).

\section{Discussion}

\section{Banded ore deposition during the sulfide stage}

\section{Fluid mixing}

The Mesozoic sulfide mineralization stage was of major economic importance and typically manifests itself as banded quartz-sulfide and calcite-sulfide ores or massive ore veins in the Upper Harz Mts. The formation of banded ores in the Upper Harz Mts. is commonly explained by mixing of ascending metal-rich brines with $\mathrm{H}_{2} \mathrm{~S}$-bearing fluids (e.g., Möller et al. 1979, 1984; Lüders and Möller 1992). Calcite that precipitated during the sulfide stage contains considerable amounts of metals such as $\mathrm{Pb}, \mathrm{Zn}, \mathrm{Mn}, \mathrm{Fe}, \mathrm{Sr}$, and REE 


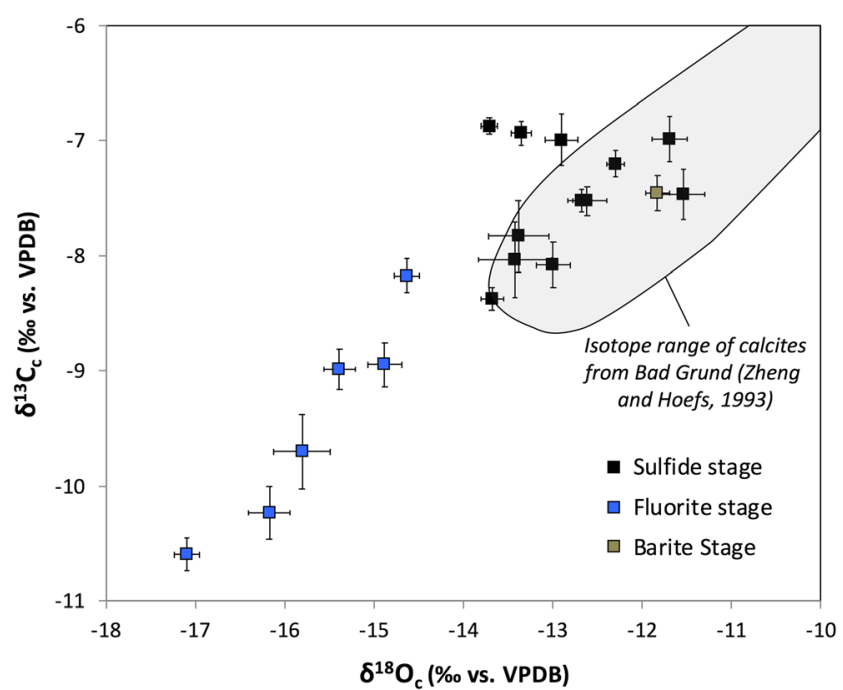

Fig. 9 Carbon and oxygen isotope signatures of calcite vein deposits from the main Mesozoic mineralization stages in the Harz Mts. The clear co-variation between $\delta^{18} \mathrm{O}_{\mathrm{c}}$ and $\delta^{13} \mathrm{C}_{\mathrm{c}}$ may be related to waterrock interactions, varying fluid temperatures or the presence of different carbon reservoirs. Fluorite-stage calcite (blue) display an overall depletion in ${ }^{13} \mathrm{C}$ and ${ }^{18} \mathrm{O}$ with respect to sulfide-stage calcite (black). Isotope measurements of hydrothermal calcite from the Bad Grund banded ore deposits in the Upper Harz Mts. from Zheng and Hoefs (1993) are given for reference

(Möller et al. 1984, 1991; Lüders 1988; Luck and Lüders 1989) and is, for that reason, believed to be associated with a metal-rich brine that ascended from a deep-seated source. Calcite contents of the veins in the Upper Harz Mts. typically increase with depth, whereas sulfide mineralization decreases (Stedingk 1993), which may be indicative of transport of metals into a shallower, $\mathrm{H}_{2} \mathrm{~S}$-bearing environment. Hence, the deposition of sulfides is assumed to result from the mixing of the ascending metal-rich brine with shallower crustal $\mathrm{H}_{2} \mathrm{~S}-$ bearing fluids derived from Paleozoic shales (Nielsen 1968; Lüders and Möller 1992). A tectonic pumping mechanism could be capable of draining different reservoirs alternately causing cyclic changes in the fluid composition (Sibson et al. 1975). Fluid mixing is often cited as a key process for depositing ore bodies in hydrothermal systems (Wilkinson 2001; Boiron et al. 2010; Bons et al. 2014), and this model is compatible with the results of this study.

Differences in $\mathrm{Cl} / \mathrm{Br}, \mathrm{Na} / \mathrm{Br}$, and $\mathrm{Na} / \mathrm{K}$ molar ratios between gangue and ore minerals (Figs. 6a and 7a) indicate that fluids from at least two different reservoirs were involved in the formation of banded ores. Both fluids are characterized by high salinity as indicated by fluid inclusion microthermometry of inclusions in ore and gangue minerals (Fig. 5). Variations in $\delta^{2} \mathrm{H}_{\mathrm{w}}$ in banded ore minerals cover a range of $40 \%$. At the temperatures recorded from the fluid inclusions for the mineralizing events, hydrogen isotope values of fluid inclusions are generally assumed to be unaffected by diagenetic alteration (Horita and Matsuo 1986; Ohba and Matsuo 1988; Mavrogenes and Bodnar 1994; Simon 2001; Baatartsogt et al. 2007a; Bakker 2009). The large isotope range observed in $\delta^{2} \mathrm{H}_{\mathrm{w}}$ is, thus, also indicative of fluids originating from different reservoirs, considering that $\delta^{2} \mathrm{H}_{\mathrm{w}}$ modifications of circulating fluids through WRI processes are generally thought to be limited due to the sheer amount of water with respect to hydrogen-bearing reactants (e.g., O'Neil and Kharaka 1976; Yeh and Epstein 1978).

\section{Deep-seated brines}

Lead isotope ratios showed that lead in galena from Mesozoic sulfide-stage deposits was derived from a homogeneous crustal source (Lévêque and Haack 1993a). Uniform Sr isotope compositions of calcite (0.713-0.714) from the most important $\mathrm{Pb}-\mathrm{Zn}$ deposits in the Upper Harz Mts. point to a homogeneous source for $\mathrm{Sr}$ as well (Lévêque and Haack 1993b). Assuming that $\mathrm{Pb}$ and $\mathrm{Sr}$ are derived from the same reservoir, alteration of granites and/or basement rocks can be excluded as possible sources of $\mathrm{Sr}$ and $\mathrm{Pb}$ in banded ores. Instead, Ordovician to Lower Carboniferous sedimentary sequences are believed to be the most probable source for the metalrich brine (Friese and Haack 1993; Lévêque and Haack 1993a, b). Schneider et al. (2003b), studying Sr isotope ratios in siderites from the Lower Harz Mts., also concluded that Paleozoic sequences are the most likely source for Sr.

Halite dissolution can be excluded as source of salinity of fluids in the Harz Mts. as it typically produces brines with $\mathrm{Cl} /$ $\mathrm{Br}$ molar ratios of 5000 to 20,000 (Fontes and Matray 1993), which are significantly higher than those recorded for the Harz system (about 200 to 650). The principal source of salinity for the deep-seated brine is rather related to seawater evaporation (Fig. 6a). The $\delta^{2} \mathrm{H}_{\mathrm{w}}$ of banded ore calcite and quartz $(-47$ to $-17 \%$ o $)$ is depleted with respect to seawater. Although the precise effects of WRI on the isotope composition of the brine are unconstrained, low $\delta^{2} \mathrm{H}_{\mathrm{w}}$ values fit well with dense seawater evaporation brines, which are typically characterized by considerable depletions in ${ }^{2} \mathrm{H}$ (Holser 1979; Knauth and Beeunas 1986).

The origin of the supposed evaporation brines seems to be enigmatic since evaporites do not occur in the Paleozoic sedimentary succession. An intriguing possibility, though, is that the seawater evaporation brines originated from the Zechstein evaporites that covered the Harz Mts. during the Mesozoic. Behr and Gerler (1987) also suggested a close relation between highly saline Permo-Triassic basinal brines and the formation of Post-Variscan mineralization in other ore districts in Germany. The increased density of Zechstein evaporite brines would have aided their descent into deep-seated Paleozoic sediments and their high chloride concentration would have made them ideal solvents for leaching metals. The driving force behind the descent of fluids may be fracture opening or the consumption at depth of water through hydration reactions with minerals (Stober and Bucher 2004). The deeply infiltrated brines ascended along faults during periodic pulses 
of tectonic activity to cause the deposition of banded ores through mixing with shallow crustal $\mathrm{H}_{2} \mathrm{~S}$-bearing brines.

$\mathrm{Cl} / \mathrm{Br}$ molar ratios of fluid inclusions hosted in calcite are lower compared to quartz (Fig. 6a), which provides an indication that the brines that were active during the calcitesulfide stage IIc had experienced greater seawater evaporation than the brines responsible for quartz precipitation. Progressively deeper reservoirs of denser fluids may have been tapped in response to tectonic activity and rupture propagation. Different reservoirs for quartz and calcite-forming brines are also supported by different $\delta^{2} \mathrm{H}_{\mathrm{w}}$ values of fluid inclusion water in quartz and calcite (Fig. 10).

The original $\delta^{18} \mathrm{O}$ ratio of the deep-seated brine is difficult to constrain since it is associated with the oxygen-bearing minerals calcite and quartz. The drop in temperature that these minerals have experienced since their deposition has likely resulted in the decreasing of $\delta^{18} \mathrm{O}_{\mathrm{w}}$ ratios due to in situ oxygen isotope re-equilibration between fluid inclusion water and the host mineral (Schwarcz et al. 1976; Matsuhisa et al. 1978; Ohba et al. 1995; Taylor 1997). This becomes evident when calculating temperatures from $\delta^{18} \mathrm{O}_{\mathrm{w}}-\delta^{18} \mathrm{O}_{\text {mineral }}$ pairs. As for banded ore calcite, the calculated temperatures range from 58 to $79^{\circ} \mathrm{C}$ using the equation of O'Neil et al. (1969). Banded ore quartz has a temperature range of 66 to $109^{\circ} \mathrm{C}$, when using the equation of Clayton et al. (1972) and $\delta^{18} \mathrm{O}_{\mathrm{qtz}}$ values ranging from 18.6 to $21.8 \%$ ov VSMOW as reported for banded ore quartz in Voigt (1984) and Zheng (1991). These calculated temperatures are considerably lower than the (pressurecorrected) temperatures of hydrothermal fluids during sulfide-stage mineralization in the Upper Harz Mts. of up to $175^{\circ} \mathrm{C}$ (Lüders et al. 1993a; this study). This suggests that the $\delta^{18} \mathrm{O}_{\mathrm{w}}$ data from the banded ore calcite and quartz probably do not represent the original values as a result of water-mineral oxygen isotope re-equilibration. As an alternative, original $\delta^{18} \mathrm{O}$ values of the brines may be calculated from the $\delta^{18} \mathrm{O}_{\mathrm{c}}$ data under the assumption of isotope equilibrium during mineral precipitation (Fig. 10). Whereas the $\delta^{18} \mathrm{O}_{\mathrm{w}}$ record of calcite and quartz should be approached with caution, fluid inclusion water in fluorite $\left(\mathrm{CaF}_{2}\right)$, sphalerite $(\mathrm{ZnS})$, chalcopyrite $\left(\mathrm{CuFeS}_{2}\right)$, and galena $(\mathrm{PbS})$ is unlikely affected by oxygen isotope exchange processes, since these minerals are devoid of oxygen.

\section{Shallow crustal fluid $\left(\mathrm{H}_{2} \mathrm{~S}\right.$ source)}

Mixing of reduced sulfur-bearing fluids with the ascending brines induced the precipitation of sulfide minerals. Detailed studies of fluid inclusions hosted in individual quartz, calcite, and sphalerite bands as well as results of previous studies (Adeyemi 1982; Lüders et al. 1993a) have shown that ore and gangue minerals (incl. banded ores) were deposited from brines of similar salinity (Fig. 5). $\mathrm{Cl} / \mathrm{Br}$ and $\mathrm{Na} / \mathrm{Br}$ ratios suggest that the reduced sulfur-bearing fluid had experienced minor evaporation (Fig. 6a). The upper limit of fluid inclusion

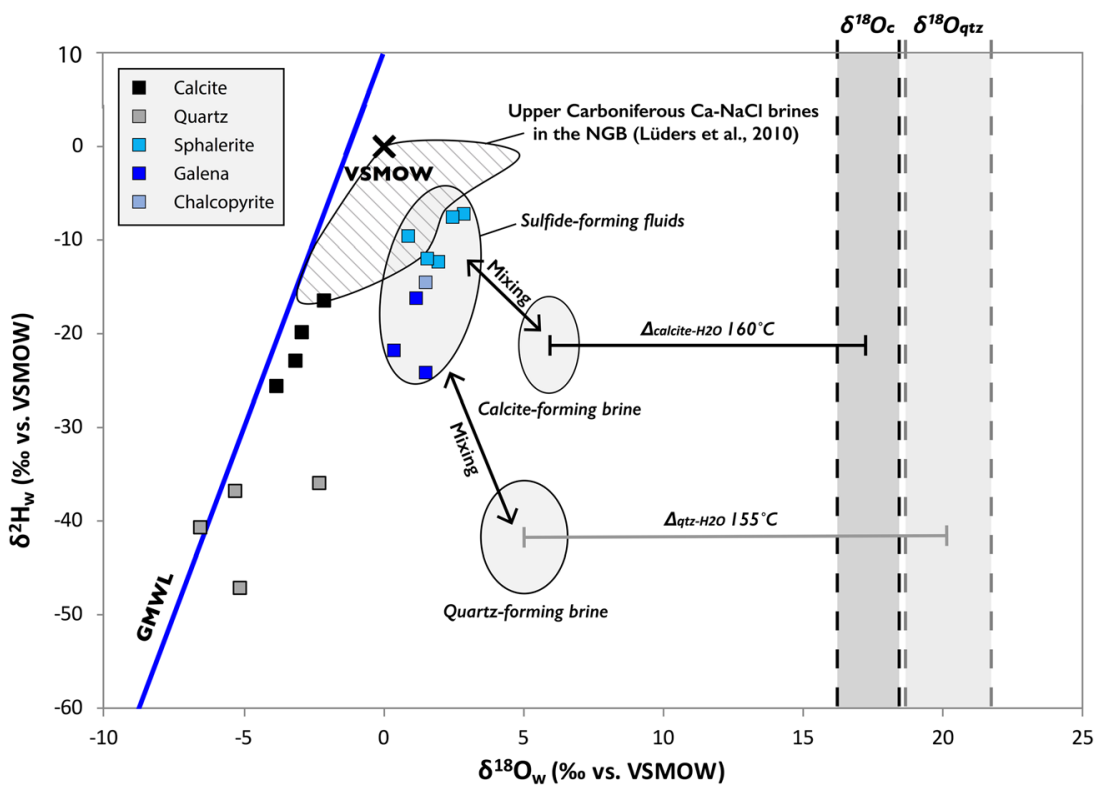

Fig. $10 \delta^{18} \mathrm{O}_{\mathrm{w}} \mathrm{vs} \delta^{2} \mathrm{H}_{\mathrm{w}}$ diagram for sulfide-stage banded ore and gangue minerals (Bad Grund, Upper Harz Mts.). Fluid inclusion $\delta^{18} \mathrm{O}_{\mathrm{w}}$ values of calcite and quartz are interpreted not to reflect their original values due to temperature-related exchange processes. The equations of O'Neil et al. (1969) and Clayton et al. (1972) were used for calculating estimated $\delta^{18} \mathrm{O}_{\mathrm{w}}$ values for the calcite-forming and quartz-forming brines by combining $\delta^{18} \mathrm{O}_{\mathrm{c}}$ and $\delta^{18} \mathrm{O}_{\mathrm{qtz}}$ values and temperature estimates of 160 and $155{ }^{\circ} \mathrm{C}$ for calcite and quartz, respectively. Measured $\delta^{2} \mathrm{H}_{\mathrm{w}}$ values in calcite and quartz are likely original. The diagram reveals a fluid mixing system with sulfide minerals and quartz/calcite associated with distinct fluid reservoirs. Furthermore, it shows that a different deep-seated fluid reservoir was accessed during the calcite-sulfide and quartz-sulfide stage. The shallow crustal fluid end-member responsible for sulfide deposition is similar to present-day Upper Carboniferous formation waters in the North German Basin 
isotopes recorded in metal sulfides $\left(-5 \%\right.$ o for $\delta^{2} \mathrm{H}_{\mathrm{w}}$ and $2 \%$ o for $\delta^{18} \mathrm{O}_{\mathrm{w}}$ ) would correspond to the reduced sulfur-bearing fluid end-member and also points to a marine fluid that experienced a minor ${ }^{18} \mathrm{O}$ enrichment due to subaerial evaporation or high-temperature WRI.

Paleozoic shale-rich units containing organic matter situated below the impermeable Zechstein evaporites are assumed to provide the main source of $\mathrm{H}_{2} \mathrm{~S}$ necessary for sulfide mineral deposition in the Harz Mts. (Nielsen 1968; Lüders and Ebneth 1993). $\mathrm{Na} / \mathrm{K}$ vs $\mathrm{Cl} / \mathrm{Br}$ diagrams of banded ore galena and sphalerite samples show the brines had experienced a significant degree of $\mathrm{K}$ enrichment (Fig. 7a), which is in line with a model that involves interaction with shales (e.g., exchange reactions with or dissolution of K-bearing clay minerals). Whereas the Permian and Mesozoic rock cover has been eroded in the present-day Harz Mts., it is preserved in large parts of the North German Basin. Interestingly, formation waters from a Carboniferous reservoir in the North German Basin (Lüders et al. 2010) display isotope values $\left(-15\right.$ to $0 \%$ o $\delta^{2} \mathrm{H}_{\mathrm{w}}$ and -3 to $4 \% o \delta^{18} \mathrm{O}_{\mathrm{w}}$ ), which are similar to those inferred for the shallow crustal fluid involved in bandedore deposition, supporting a provenance from the Paleozoic units. Furthermore, it is noteworthy that $\mathrm{CaCl}_{2}-\mathrm{NaCl}-\mathrm{H}_{2} \mathrm{O}$ Rotliegend brines, which reach up to $330 \mathrm{~g} / \mathrm{l}$ of total dissolved solids (TDS), show similar $\mathrm{Cl} / \mathrm{Br}$ and $\mathrm{Na} / \mathrm{Br}$ ratios as the fluid inclusions in sulfide minerals (Lüders et al. 2010).

Fluid systems involving highly saline deep-seated brines that ascend to mix with shallow crustal fluids are often seen to be associated with the deposition of $\mathrm{Pb}-\mathrm{Zn}$ ores (Boiron et al. 2010). Mixing of fluids from different crustal levels is hydromechanically feasible only when fluids mix during their ascent to shallower crustal levels (i.e., no simultaneous upwelling and downwelling of fluids) as set forth in the model of Bons et al. (2014). In this model, the amount of shallow crustal fluids may vary depending on the upwelling rate of deep-seated fluid batches; it can, thus, be reconciled with the observed vein banding. For many ore deposits, the driving force for the expulsion of deep-seated ore-forming fluids is related to periods of crustal extension. For example, the opening of the North Atlantic during the Jurassic to Early Cretaceous initiated extensional tectonic regimes that facilitated the deposition of ores throughout Europe (Muchez et al. 2005; Boiron et al. 2010) and basement-hosted Ag ores in the Anti-Atlas Mountains of Morocco (Essarraj et al. 2005). On a western European scale, continental rifting of the Rhine Graben instigated ore deposition during the Tertiary (Staude et al. 2009).

\section{Barite mineralization stage}

Barite veins were deposited at shallow crustal levels during the Cretaceous. The few studied barite samples display significantly lower $\delta^{2} \mathrm{H}_{\mathrm{w}}$ values compared to the other analyzed minerals (Fig. 8). The position of barite samples on the GMWL could point to an influx of meteoric water (about $75 \%$ or for $\delta^{2} \mathrm{H}_{\mathrm{w}}$ and $-10.5 \%$ o for $\delta^{18} \mathrm{O}_{\mathrm{w}}$ ) into the system that may possibly have leached sulfate from the Zechstein evaporites to facilitate barite mineralization. The supply of $\mathrm{SO}_{4}{ }^{2-}$ bearing meteoric waters during the barite mineralization stage was previously inferred from a general drop in fluid inclusion salinities (Lüders et al. 1993a).

Although fluid inclusion isotope data are consistent with traditional ideas on fluid flow during the barite stage, we are cautious with this interpretation since fluid inclusions in barite are relatively prone to remobilization and leakage (Ulrich and Bodnar 1988). Secondary monophase aqueous fluid inclusions predominate in barite, and although this could result from low entrapment temperatures, it could also be related to recrystallization or late infiltration of meteoric fluids at nearsurface conditions. The isotopic resemblance of fluid inclusions in barite to present-day rainwater in the region (Stumpp et al. 2014) would support this latter hypothesis. Furthermore, the extent of post-depositional oxygen isotope re-equilibration of fluid inclusion water in barite cannot be assessed, since we do not dispose of oxygen isotope data of the mineral phase. Altogether, the exact reason for the recorded meteoric isotope character of fluid inclusion water in barite cannot be definitively constrained.

\section{Fluorite mineralization stage}

Fluorite-(calcite \pm quartz) mineralization represents the last stage of Mesozoic vein-type deposition in the Harz Mts. and is mostly encountered in the vicinity of Upper Carboniferous granites and Permian volcanic rocks in the Middle and Lower Harz Mts. (Fig. 1). The origin of fluorine is assumed to be metavolcanic Lower Permian rocks (Schneider et al. 2003a) and/or dispersed fluorite enrichments in the crystalline basement (Lüders and Möller 1992). Whereas geochemical data of banded sulfide ores from the Upper Harz Mts. point to a mixing system with fluids derived from different Paleozoic reservoirs, the origin of fluorite-forming fluids has remained largely unresolved.

Fluid inclusions in fluorite samples show an isotope range for fluorite-forming fluids from 2.5 to $6.5 \%$ for $\delta^{18} \mathrm{O}_{\mathrm{w}}$ and -31 to $5 \%$ o for $\delta^{2} \mathrm{H}_{\mathrm{w}}$. This wide isotope range could indicate interaction of brines with different rocks and/or that different fluid reservoirs were being accessed during the fluorite stage. Calculation of $\delta^{18} \mathrm{O}$ values of fluids associated with calcite precipitation during the period of fluorite mineralization - using the equation of O'Neil et al. (1969), with the measured $\delta^{18} \mathrm{O}_{\mathrm{c}}$ values and assuming a precipitation temperature of $175{ }^{\circ} \mathrm{C}$ (Augustin 1993; Lüders et al. 1993a) - brings the fluid inclusion isotope range of calcite coincident with the range of the fluorite samples (Fig. 11). This suggests that fluorite and calcite precipitated 
Fig. $11 \delta^{18} \mathrm{O}_{\mathrm{w}}$ vs $\delta^{2} \mathrm{H}_{\mathrm{w}}$ cross plot of fluorite-calcite assemblages. Original $\delta^{18} \mathrm{O}_{\mathrm{w}}$ values of calcite samples are calculated using the equation of O'Neil et al. (1969) for a precipitation temperature of $175^{\circ} \mathrm{C}$. Original fluid inclusion isotope signatures of fluorite and associated calcite overlap, which points to a close co-genetic relationship and similar fluid sources. Fluid inclusions in calcite experienced an oxygen isotope depletion of on average $9.2 \%$ after entrapment forced by decreasing ambient temperatures during uplift

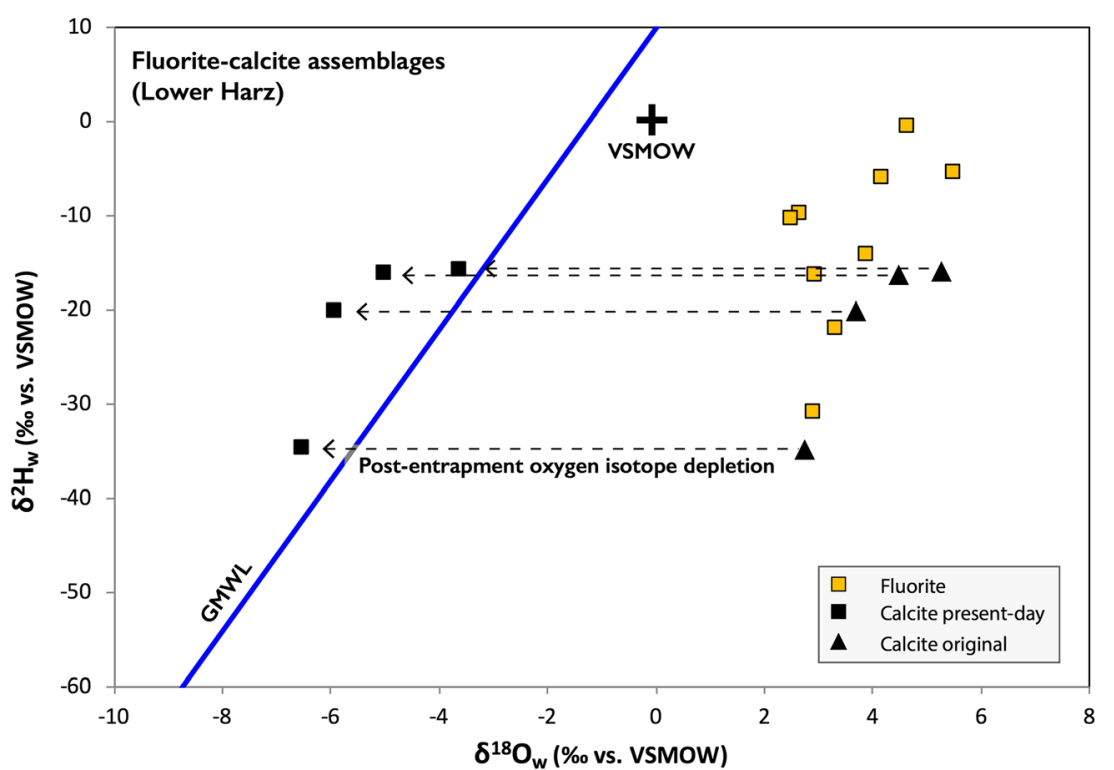

from fluids derived from similar sources, which is also supported by overlapping $\mathrm{Na} / \mathrm{K}$ molar ratios for these two mineral types in the Lower Harz Mts. (Fig. 7c). Radiogenic Sr isotope ratios in fluorite (Schneider et al. 2003b) and K enrichments in fluorite-hosted fluid inclusions would be compatible with a model that invokes refluxing Zechstein brines that interacted with deep-seated crystalline rocks and re-ascended along deeply penetrating compressional structures that were activated during Late Cretaceous tectonics (Franzke and Zerjadtke 1993). $\mathrm{The} \mathrm{Cl} / \mathrm{Br}$ molar ratios of vein-forming fluids during the fluorite stage (Fig. 6c) are significantly lower compared to the sulfidestage banded ores and even suggest seawater evaporation past the end of halite saturation (Fontes and Matray 1993). This is in line with the observation of halite daughter crystal-bearing fluid inclusions hosted in some fluorite samples (Fig. 4f). The progressive tapping of more highly evaporated fluids through time would correspond with the expected stratification in fluid reservoirs based on density, with the densest fluids occupying the deepest crustal levels (Bons et al. 2014).

In the previous discussion, we provide a model in which the most important $\mathrm{Pb}-\mathrm{Zn}$ and fluorite vein-type deposits in the Harz precipitated from deep-seated seawater-evaporated brines that mixed with variable amounts of shallow crustal fluids. The model of mineralizing fluids originating as seawater and/or evaporated seawater has been shown to hold for numerous other basin-hosted $\mathrm{Pb}-\mathrm{Zn}$ ore and fluorite deposits (e.g., Behr and Gerler 1987; Gleeson et al. 2001; Heijlen et al. 2003; Grandia et al. 2003; Muchez et al. 2005; Stoffell et al. 2008; Leach et al. 2010) and in genetic models for Proterozoic U deposits (Derome et al. 2007; Boiron et al. 2010; Richard et al. 2011, 2013). Ore-forming seawater evaporation brines are systematically characterized by depletions in ${ }^{2} \mathrm{H}$ similar in magnitude to those we observe (Baatartsogt et al. 2007a; Wilkinson 2010; Richard et al.
2013) and low $\mathrm{Cl} / \mathrm{Br}$ ratios (Bucher and Stober 2010; Fusswinkel et al. 2013).

\section{Conclusions}

Isotopic $\left(\delta^{2} \mathrm{H}_{\mathrm{w}}\right.$ and $\left.\delta^{18} \mathrm{O}_{\mathrm{w}}\right)$ and salinity data of bulk fluid inclusions in ore and gangue minerals provide new constraints on the flow patterns and origins of ore-forming fluids in the Harz Mts. Considerable variations in fluid inclusion isotope ratios and salinities suggest that various fluid reservoirs were involved in the deposition of a wide variety of vein-type mineralization in the Harz Mts. Zechstein brines are recognized to be of major importance throughout the main mineralization stages during the Mesozoic. These dense, evaporated marine waters descended along fault structures to leach metals and other oreforming constituents from deep-seated Paleozoic sediments (Upper Harz Mts.) and crystalline rocks (Lower Harz Mts.). Episodic events of tectonic activity forced the metal-rich brines upwards to enable ore deposition at shallower crustal levels.

During the Jurassic, the deep-seated brines recharged along shear zones and experienced mixing with $\mathrm{H}_{2} \mathrm{~S}$-bearing brines from shallower Paleozoic shale units, which resulted in the deposition of banded quartz-sulfide and calcite-sulfide ores in the Upper Harz Mts. Continued fracture propagation to greater depths allowed the leaching of fluorine-bearing basement rocks and the recharge of highly saline brines that deposited fluorite mineralization in the Middle and Lower Harz Mts. during the Cretaceous.

Fluid inclusion isotope data from barite deposits have a meteoric signature. This could point either to infiltration of meteoric fluids into the system during the barite mineralization stage, or to later alteration of fluid inclusion isotope ratios due to exposure to surface waters. 
Acknowledgments Open access funding provided by Max Planck Society. We thank the Museum für Naturkunde Berlin and the Technical University Berlin for providing samples from their mineral collections. Suzan Verdegaal is thanked for technical support in the stable isotope laboratory at the VU University Amsterdam. Three anonymous reviewers are acknowledged for their critical reviews and valuable suggestions for improvement. We are indebted to Mineralium Deposita chief editor B. Lehmann for fair handling of this manuscript.

\section{Compliance with ethical standards}

Conflict of interest The authors declare that they have no conflict of interest.

Open Access This article is distributed under the terms of the Creative Commons Attribution 4.0 International License (http:// creativecommons.org/licenses/by/4.0/), which permits unrestricted use, distribution, and reproduction in any medium, provided you give appropriate credit to the original author(s) and the source, provide a link to the Creative Commons license, and indicate if changes were made.

\section{References}

Adeyemi A (1982) Vergleichende mikrothermometrische Untersuchungen an Flüssigkeitseinschlüssen aus hydrothermalen Mineralisationsen der rheno-herzynischen Zone. Unpub. $\mathrm{PhD}$ thesis University Göttingen, $123 \mathrm{p}$

Augustin O (1993) Mineralchemische und mikrothermometrische Untersuchungen an den Gangmineralisationen des Unterharzes. Unpub. $\mathrm{PhD}$ thesis University Hamburg, $138 \mathrm{p}$

Baatartsogt B, Schwinn G, Wagner T, Taubald H, Beitter T, Markl G (2007a) Contrasting paleofluid systems in the continental basement: a fluid inclusion and stable isotope study of hydrothermal vein mineralization, Schwarzwald district, Germany. Geofluids 7:123-147. https://doi.org/10.1111/j.1468-8123.2007.00169.x

Baatartsogt B, Wagner T, Taubald H, Mierdel K, Markl G (2007b) Hydrogen isotope determination of fluid inclusion water from hydrothermal fluorite: constraining the effect of the extraction technique. Chem Geol 244:474-482. https://doi.org/10.1016/j. chemgeo.2007.06.031

Bakker RJ (2009) Reequilibration of fluid inclusions: bulk-diffusion. Lithos 112:277-288. https://doi.org/10.1016/j.lithos.2009.03.006

Banks DA, Giuliani G, Yardley BWD, Cheilletz A (2000) Emerald mineralisation in Colombia: fluid chemistry and the role of brine mixing. Mineral Deposita 35:699-713. https://doi.org/10.1007/ s001260050273

Banks DA, Boyce AJ, Samson IM (2002) Constraints on the origins of fluids forming Irish $\mathrm{Zn}-\mathrm{Pb}-\mathrm{Ba}$ deposits: evidence from the composition of fluid inclusions. Econ Geol 97:471-480. https://doi.org/10. 2113/gsecongeo.97.3.471

Behr H-J, Gerler J (1987) Inclusions of sedimentary brines in postVariscan mineralizations in the Federal Republic of Germany-a study by neutron activation analysis. Chem Geol 61:65-77. https:// doi.org/10.1016/0009-2541(87)90028-3

Behr H-J, Horn EE, Frentzel-Beyme K, Reutel C (1987) Fluid inclusion characteristics of the Variscan and post-Variscan mineralizing fluids in the Federal Republic of Germany. Chem Geol 61:273-285

Bertotti G, De Graaf S, Bisdom K, Oskam B, Vonhof HB, Bezerra FHR, Reijmer JJG, Cazarin CL (2017) Fracturing and fluid-flow during post-rift subsidence in carbonates of the Jandaíra Formation, Potiguar Basin, NE Brazil. Basin Res 29:836-853. https://doi.org/ $10.1111 /$ bre. 12246
Boiron M-C, Cathelineau M, Richard A (2010) Fluid flows and metal deposition near basement /cover unconformity: lessons and analogies from $\mathrm{Pb}-\mathrm{Zn}$-F-Ba systems for the understanding of Proterozoic U deposits. Geofluids 10:270-292. https://doi.org/10.1111/j.14688123.2010.00289.x

Bons PD, Fusswinkel T, Gomez-Rivas E, Markl G, Wagner T, Walter B (2014) Fluid mixing from below in unconformity-related hydrothermal ore deposits. Geology 42:1035-1038. https://doi.org/10.1130/G35708.1

Borisenko AS (1998) Study of salt composition of solutions of gas-liquid inclusions in minerals by cryometric method. Sov Geol Geophys 18: $11-19$

Bormann P, Bankwitz P, Conrad P, Oelsner C (1989) Crustal structure and development in Central Europe. Gerlands Beitr Zur Geophys 98: 353-367

Bucher K, Stober I (2010) Fluids in the upper continental crust. Geofluids 10:241-253. https://doi.org/10.1111/j.1468-8123.2010.00279.x

Clayton RN, O'Neil JR, Mayeda TK (1972) Oxygen isotope exchange between quartz and water. J Geophys Res 77:3057-3067. https:// doi.org/10.1029/JB077i017p03057

Craig H (1961) Isotopic variations in meteoric waters. Science 133:17021703. https://doi.org/10.1126/science.133.3465.1702

Dahlgrün F (1950) Die zonale Verbreitung der Gangformation des Brockenplutons im Harz. Erzmetall 3:150-153

Davis DW, Lowenstein TK, Spencer RJ (1990) Melting behavior of fluid inclusions in laboratory-grown halite crystals in the systems $\mathrm{NaCl}-$ $\mathrm{H} 2 \mathrm{O}, \mathrm{NaCl}-\mathrm{KCl}-\mathrm{H} 2 \mathrm{O}, \mathrm{NaCl}-\mathrm{MgCl} 2-\mathrm{H} 2 \mathrm{O}$, and NaCl-CaCl2-H2O. Geochim Cosmochim Acta 54:591-601. https://doi.org/10.1016/ 0016-7037(90)90355-O

Davisson ML, Criss RE (1996) Na-Ca-Cl relations in basinal fluids. Geochim Cosmochim Acta 60:2743-2752. https://doi.org/10.1016/ 0016-7037(96)00143-3

De Graaf S, Reijmer JJG, Bertotti GV, Bezerra FHR, Cazarin CL, Bisdom K, Vonhof HB (2017) Fracturing and calcite cementation controlling fluid flow in the shallow-water carbonates of the Jandaíra Formation, Brazil. Mar Pet Geol 80:382-393. https://doi.org/10. 1016/j.marpetgeo.2016.12.014

De Graaf S, Nooitgedacht CW, Le Goff J, Van der Lubbe HJL, Vonhof HB, Reijmer JJG (2019) Fluid flow evolution in the Albanide foldand-thrust belt: insights from $\delta 2 \mathrm{H}$ and $\delta 18 \mathrm{O}$ isotope ratios of fluid inclusions. AAPG Bull. https://doi.org/10.1306/02151918034

Derome D, Cathelineau M, Fabre C, Boiron M-C, Banks D, Lhomme T, Cuney M (2007) Paleo-fluid composition determined from individual fluid inclusions by Raman and LIBS: application to midproterozoic evaporitic $\mathrm{Na}-\mathrm{Ca}$ brines (Alligator Rivers Uranium Field, northern territories Australia). Chem Geol 237:240-254. https://doi.org/10.1016/j.chemgeo.2006.10.015

Essarraj S, Boiron M-C, Cathelineau M, Banks DA, Benharref M (2005) Penetration of surface-evaporated brines into the Proterozoic basement and deposition of Co and Ag at Bou Azzer (Morocco): evidence from fluid inclusions. J Afr Earth Sci 41:25-39. https://doi. org/10.1016/j.jafrearsci.2005.03.001

Fontes JC, Matray JM (1993) Geochemistry and origin of formation brines from the Paris Basin, France. Chem Geol 109:149-175. https://doi.org/10.1016/0009-2541(93)90068-T

Franke W (1989) Tectonostratigraphic units in the Variscan belt of central Europe. In: Geological Society of America Special Papers. Geological Society of America, pp 67-90

Franzke HJ, Zerjadtke W (1993) Structural control of hydrothermal vein mineralizations in the Lower Harz Mountains. Monogr Ser Mineral Deposits 30:13-33

Friese K, Haack U (1993) Lead isotopes in the Brocken granite. Monogr Ser Mineral Deposits 30:279-284

Fusswinkel T, Wagner T, Wälle M, Wenzel T, Heinrich CA, Markl G (2013) Fluid mixing forms basement-hosted $\mathrm{Pb}-\mathrm{Zn}$ deposits: insight from metal and halogen geochemistry of individual fluid inclusions. Geology 41:679-682. https://doi.org/10.1130/G34092.1 
Gleeson SA, Wilkinson JJ, Stuart FM, Banks DA (2001) The origin and evolution of base metal mineralising brines and hydrothermal fluids, South Cornwall, UK. Geochim Cosmochim Acta 65:2067-2079. https://doi.org/10.1016/S0016-7037(01)00579-8

Grandia F, Canals A, Cardellach E, Banks DA, Perona J (2003) Origin of ore-forming brines in sediment-hosted $\mathrm{Zn}-\mathrm{Pb}$ deposits of the Basque-Cantabrian Basin, northern Spain. Econ Geol 98:13971411. https://doi.org/10.2113/gsecongeo.98.7.1397

Grant K, Gleeson SA, Roberts S (2003) The high-temperature behavior of defect hydrogen species in quartz: implications for hydrogen isotope studies. Am Mineral 88:262-270. https://doi.org/10.2138/am-20032-302

Haack U, Lauterjung J (1993) $\mathrm{Rb} / \mathrm{Sr}$ dating of hydrothermal overprint in Bad Grund by mixing lines. Monogr Ser Mineral Deposits 30:103114

Hagedorn B, Lippolt HJ (1993) Isotopic age constraints for epigenetic mineralizations in the Harz Mountains (Germany) from $\mathrm{K}-\mathrm{Ar}$, $40 \mathrm{Ar} / 39 \mathrm{Ar}$ and $\mathrm{Rb}-\mathrm{Sr}$ data of authigenic K-feldspars. Monogr Ser Mineral Deposits 30:87-102

Heijlen W, Muchez P, Banks DA, Schneider J, Kucha H, Keppens E (2003) Carbonate-hosted $\mathrm{Zn}-\mathrm{Pb}$ deposits in Upper Silesia, Poland: origin and evolution of mineralizing fluids and constraints on genetic models. Econ Geol 98:911-932. https://doi.org/10.2113/ gsecongeo.98.5.911

Holser AWT (1979) Trace elements and isotopes in evaporates. In: Marine minerals. Mineralogical Association of America. Rev Mineral 6:295-346

Horita J, Matsuo S (1986) Extraction and isotopic analysis of fluid inclusions in halites. Geochem J 20:261-272. https://doi.org/10.2343/ geochemj.20.261

Jacobsen W, Schneider H (1950) Die Erzgänge des nordwestlichen Oberharzes - Eine Erläuterung zur Gangkarte 1:25000. Geol Jahrb 65:707-768

Kaden, H., 2002, The source and composition of fluids associated with mineralization in the Harz Mountains, MSc thesis: University of Leeds, $79 \mathrm{p}$

Kesler SE, Appold MS, Martini AM, Walter LM, Huston TJ, Richard Kyle J (1995) Na-Cl-Br systematics of mineralizing brines in Mississippi Valley-type deposits. Geology 23:641-644. https://doi. org/10.1130/0091-7613(1995)023<0641:NCBSOM>2.3.CO;2

Knauth LP, Beeunas MA (1986) Isotope geochemistry of fluid inclusions in Permian halite with implications for the isotopic history of ocean water and the origin of saline formation waters. Geochim Cosmochim Acta 50:419-433. https://doi.org/10.1016/00167037(86)90195-X

Leach DL, Bradley DC, Huston D, Pisarevsky SA, Taylor RD, Gardoll SJ (2010) Sediment-hosted lead-zinc deposits in Earth history. Econ Geol 105:593-625. https://doi.org/10.2113/gsecongeo.105.3.593

Lévêque J, Haack U (1993a) $\mathrm{Pb}$ isotopes of hydrothermal ores in the Harz. Monogr Ser Mineral Deposits 30:197-210

Lévêque J, Haack U (1993b) Sr isotopes in calcites of hydrothermal veins in the Harz and possible sources of solutions. Monogr Ser Mineral Deposits 30:159-168

Luck JH, Lüders V (1989) Determination of trace metals in hydrothermal calcites by ICP-methods. Mikrochim Acta 99:329-336. https://doi. org/10.1007/BF01244688

Lüders V (1984) Mikrothermometrische Untersuchungen an Flüssigkeitseinschlüssen in Erz- und Gangmineralien vom Schadenbeeksglücker Gang (Südwestharz) und vom Todberger Gangzug (Nordwestharz). MSc thesis: University of Göttingen $78 \mathrm{p}$

Lüders V (1988) Geochemische Untersuchungen an Erz- und Gangartmineralen des Harzes. Berl Geowiss Abh A93:74p

Lüders V, Ebneth J (1993) Sulfur isotopes in shales and their relation to vein sulfides (and barite) of the Upper and Middle Harz Mountains. Monogr Ser Mineral Deposits 30:231-240
Lüders V, Möller P (1992) Fluid evolution and ore deposition in the Harz Mountains (Germany). Eur J Mineral 4:1053-1068. https://doi.org/ $10.1127 /$ ejm $/ 4 / 5 / 1053$

Lüders V, Reutel C (1998) Formation of hydrothermal vein mineralizations in the SW Harz Mountains and the St. Andreasberg mining district (Germany). Freib Forsch H C 475:107-120

Lüders V, Gerler J, Hein UF, Reutel C (1993a) Chemical and thermal development of ore-forming solutions in the Harz Mountains: a summary of fluid inclusion studies. Monogr Ser Mineral Deposits 30:117-132

Lüders V, Möller P, Dulski P (1993b) REE fractionation in carbonates and fluorite. Monogr Ser Mineral Deposits 30:133-150

Lüders V, Stendingk K, Franzke HJ (1993c) Review of geological setting and mineral paragenesis. Monogr Ser Mineral Deposits 30:5-11

Lüders V, Plessen B, Romer RL, Weise SM, Banks DA, Hoth P, Dulski P, Schettler G (2010) Chemistry and isotopic composition of Rotliegend and Upper Carboniferous formation waters from the North German Basin. Chem Geol 276:198-208. https://doi.org/10. 1016/j.chemgeo.2010.06.006

Matsuhisa Y, Goldsmith JR, Clayton RN (1978) Mechanisms of hydrothermal crystallization of quartz at $250^{\circ} \mathrm{C}$ and 15 kbar. Geochim Cosmochim Acta 42:173-182. https://doi.org/10.1016/00167037(78)90130-8

Mavrogenes JA, Bodnar RJ (1994) Hydrogen movement into and out of fluid inclusions in quartz: experimental evidence and geologic implications. Geochim Cosmochim Acta 58:141-148. https://doi.org/ 10.1016/0016-7037(94)90452-9

Mohr K (1993) Geologie und Minerallagerstätten des Harzes. E. Schweizerbart'sche Verlagsbuchandlung, Stuttgart

Möller P, Lüders V (1993) Synopsis. Monogr Ser Mineral Deposits 30: 285-291

Möller P, Morteani G, Hoefs J, Parekh PP (1979) The origin of the orebearing solution in the $\mathrm{Pb}-\mathrm{Zn}$ veins of the western Harz, Germany, as deduced from rare-earth element and isotope distributions in calcites. Chem Geol 26:197-215. https://doi.org/10.1016/00092541(79)90046-9

Möller P, Morteani G, Dulski P (1984) The origin of the calcites from Pb$\mathrm{Zn}$ veins in the Harz Mountains, Federal Republic of Germany. Chem Geol 45:91-112. https://doi.org/10.1016/0009-2541(84) 90117-7

Möller P, Lüders V, Schröder J, Luck J (1991) Element partitioning in calcite as a function of solution flow rate: a study on vein calcites from the Harz Mountains. Mineral Deposita 26:175-179. https:// doi.org/10.1007/BF00209255

Möller P, Lüders V, De Lucia M (2017) Formation of Rotliegend Ca-Cl brines in the North German Basin compared to analogues in the geological record. Chem Geol 459:32-42. https://doi.org/10.1016/ j.chemgeo.2017.04.001

Muchez P, Heijlen W, Banks D, Blundell D, Boni M, Grandia F (2005) 7: extensional tectonics and the timing and formation of basin-hosted deposits in Europe. Ore Geol Rev 27:241-267. https://doi.org/10. 1016/j.oregeorev.2005.07.013

Nielsen H (1968) Schwefel-Isotopenverhältnisse aus St. Andreasberg und anderer Erzvorkommen des Harzes. N Jb Miner Abh 109:289-321

O'Neil JR, Kharaka YK (1976) Hydrogen and oxygen isotope exchange reactions between clay minerals and water. Geochim Cosmochim Acta 40:241-246. https://doi.org/10.1016/0016-7037(76)90181-2

O’Neil JR, Clayton RN, Mayeda TK (1969) Oxygen isotope fractionation in divalent metal carbonates. J Chem Phys 51:5547-5558. https:// doi.org/10.1063/1.1671982

Ohba T, Matsuo S (1988) Precise determination of hydrogen and oxygen isotope ratios of water in fluid inclusions of quartz and halite. Geochem J 22:55-68. https://doi.org/10.2343/geochemj.22.55

Ohba T, Kazahaya K, Matsuo S (1995) Diffusional 180 loss from inclusion water in a natural hydrothermal quartz from the Kaneuchi 
tungsten deposit, Japan. Geochim Cosmochim Acta 59:3039-3304. https://doi.org/10.1016/0016-7037(95)00193-X

Potter RW (1977) Pressure corrections for fluid-inclusion homogenization temperatures based on the volumetric properties of the system $\mathrm{NaCl}-\mathrm{H} 2 \mathrm{O}$. J Res US Geol Surv 5:603-607

Richard A, Banks DA, Mercadier J, Boiron M-C, Cuney M, Cathelineau M (2011) An evaporated seawater origin for the ore-forming brines in unconformity-related uranium deposits (Athabasca Basin, Canada): $\mathrm{Cl} / \mathrm{Br}$ and $837 \mathrm{Cl}$ analysis of fluid inclusions. Geochim Cosmochim Acta 75:2792-2810. https://doi.org/10.1016/j.gca. 2011.02.026

Richard A, Boulvais P, Mercadier J, Boiron M-C, Cathelineau M, Cuney M, France-Lanord C (2013) From evaporated seawater to uraniummineralizing brines: isotopic and trace element study of quartzdolomite veins in the Athabasca system. Geochim Cosmochim Acta 113:38-59. https://doi.org/10.1016/j.gca.2013.03.009

Schneider J, Haack U, Stedingk K (2003a) Rb-Sr dating of epithermal vein mineralization stages in the eastern Harz Mountains (Germany) by paleomixing lines. Geochim Cosmochim Acta 67:1803-1819. https://doi.org/10.1016/S0016-7037(02)01223-1

Schneider J, Haack U, Stedingk K (2003b) A Sr isotope study on fluorite and siderite from post-orogenic mineral veins in the eastern Harz Mountains, Germany. Mineral Deposita 38:984-991. https://doi. org/10.1007/s00126-002-0332-1

Schwarcz HP, Harmon RS, Thompson P, Ford DC (1976) Stable isotope studies of fluid inclusions in speleothems and their paleoclimatic significance. Geochim Cosmochim Acta 40:657-665. https://doi. org/10.1016/0016-7037(76)90111-3

Sibson RH, Moore JMM, Rankin AH (1975) Seismic pumping - a hydrothermal fluid transport mechanism. J Geol Soc 131:653-659. https://doi.org/10.1144/gsjgs.131.6.0653

Simon K (2001) Does $\delta$ D from fluid inclusion in quartz reflect the original hydrothermal fluid? Chem Geol 177:483-495. https://doi.org/ 10.1016/S0009-2541(00)00417-4

Spencer RJ, Møller N, Weare JH (1990) The prediction of mineral solubilities in natural waters: a chemical equilibrium model for the Na$\mathrm{K}-\mathrm{Ca}-\mathrm{Mg}-\mathrm{Cl}-\mathrm{SO} 4-\mathrm{H} 2 \mathrm{O}$ system at temperatures below $25^{\circ} \mathrm{C}$. Geochim Cosmochim Acta 54:575-590. https://doi.org/10.1016/ 0016-7037(90)90354-N

Stahl A (1929) Zur Tektonik des westlichen Oberharzes. Sitz Ber Preuss Geol A 4:118-126

Staude S, Bons PD, Markl G (2009) Hydrothermal vein formation by extension-driven dewatering of the middle crust: an example from SW Germany. Earth Planet Sci Lett 286:387-395. https://doi.org/10. 1016/j.eps1.2009.07.012

Stedingk K (1993) The west field orebody II of the Bad Grund Mine: a case study. Monogr Ser Mineral Deposits 30:55-64

Stedingk K (2012) Geologie und Erzlagerstätten im Oberharz. Exkursf und Veröfftl DGG 247:9-81

Stedingk K, Stoppel D (1993) Stratigraphy, petrography, paragenesis, and tectonic features of the Upper and Middle Harz Vein Districts. Monogr Ser Mineral Deposits 30:34-54

Stober I, Bucher K (2004) Fluid sinks within the earth's crust. Geofluids 4:143-151. https://doi.org/10.1111/j.1468-8115.2004.00078.x

Stoffell B, Appold MS, Wilkinson JJ, McClean NA, Jeffries TE (2008) Geochemistry and evolution of Mississippi Valley-type mineralizing brines from the Tri-State and northern Arkansas districts determined by LA-ICP-MS microanalysis of fluid inclusions. Econ Geol 103: 1411-1435. https://doi.org/10.2113/gsecongeo.103.7.1411

Stoppel D, Gundlach H, Heberling E (1983) Schwer- und Flußspatlagerstätten des Südwestharzes. Geol Jahrb D 54:269

Stumpp C, Klaus J, Stichler W (2014) Analysis of long-term stable isotopic composition in German precipitation. J Hydrol 517:351-361. https://doi.org/10.1016/j.jhydrol.2014.05.034

Taylor HP (1997) Oxygen and hydrogen isotope relationships in hydrothermal mineral deposits. In: Barnes HL (ed) Geochemistry of hydrothermal ore deposits, 3rd edn. Wiley, New York, pp 229-302

Ulrich MR, Bodnar RJ (1988) Systematics of stretching of fluid inclusions; II, barite at $1 \mathrm{~atm}$ confining pressure. Econ Geol 83:10371046. https://doi.org/10.2113/gsecongeo.83.5.1037

Voigt I (1984) Geochemische Untersuchungen ud $87 \mathrm{Sr} / 86 \mathrm{Sr}$ Isotopenbestimmungen an Gangarten und am Nebengestein der Erlagerstätte Grund (Oberharz). $\mathrm{PhD}$ thesis University Göttingen, $170 \mathrm{p}$

Vonhof HB, Van Breukelen MR, Postma O, Rowe PJ, Atkinson TC, Kroon $\mathrm{D}$ (2006) A continuous-flow crushing device for on-line $\delta 2 \mathrm{H}$ analysis of fluid inclusion water in speleothems. Rapid Commun Mass Spectrom 20:2553-2558. https://doi.org/10.1002/rcm.2618

Walter LM, Stueber AM, Huston TJ (1990) Br-Cl-Na systematics in Illinois basin fluids: constraints on fluid origin and evolution. Geology 18:315-318. https://doi.org/10.1130/0091-7613(1990) 018<0315:BCNSII $>2.3 . \mathrm{CO} ; 2$

Wilke A (1952) Die Erzgänge von St. Andreasberg im Rahmen des Mittelharz-Ganggebietes. Geol Jahrb Beih 7:1-228

Wilkinson JJ (2001) Fluid inclusions in hydrothermal ore deposits. Lithos 55:229-272. https://doi.org/10.1016/S0024-4937(00)00047-5

Wilkinson JJ (2010) A review of fluid inclusion constraints on mineralization in the Irish ore field and implications for the genesis of sediment-hosted Zn-Pb deposits. Econ Geol 105:417-442. https:// doi.org/10.2113/gsecongeo.105.2.417

Yeh H-W, Epstein S (1978) Hydrogen isotope exchange between clay minerals and sea water. Geochim Cosmochim Acta 42:140-143. https://doi.org/10.1016/0016-7037(78)90224-7

Zhang Y-G, Weisbrod A (1988) Experimental investigation of P-VTX and immiscibility in the system $\mathrm{H} 2 \mathrm{O}-\mathrm{LiCl}$, using the synthetic fluid inclusion technique. Chem Geol 70:166 (abstr). https://doi.org/10. 1016/0009-2541(88)90689-4

Zheng Y-F (1991) C-, O-, und S-Isotopengeochemische Untersuchungen an hydrothermalen Lagerstätten des Harzes. PhD thesis, University of Göttingen: 1-130

Zheng Y-F, Hoefs J (1993) Carbon and oxygen isotopic covariations in hydrothermal calcites: theoretical modeling on mixing processes and application to $\mathrm{Pb}-\mathrm{Zn}$ deposits in the Harz Mountains, Germany. Mineral Deposita 28:78-89. https://doi.org/10.1007/BF00196332

Publisher's note Springer Nature remains neutral with regard to jurisdictional claims in published maps and institutional affiliations. 